$0<r^{2} \quad B-402$

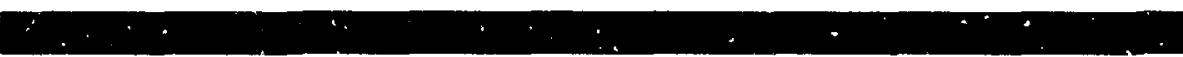

\title{
NEUTRON ACTIVATION ANALYSIS
}

AT THE LIVERMORE POOL-TYPE REACTOR

FOR THE ENVIRONMENTAL RESEARCH PROGRAM

\author{
R. C. Ragaini \\ R. E. Heft. \\ D. Garvis
}

July 2, 1976

Prepared for U.S. Energy Research \& Development

Administration under contract No. W-7405-Eng-48

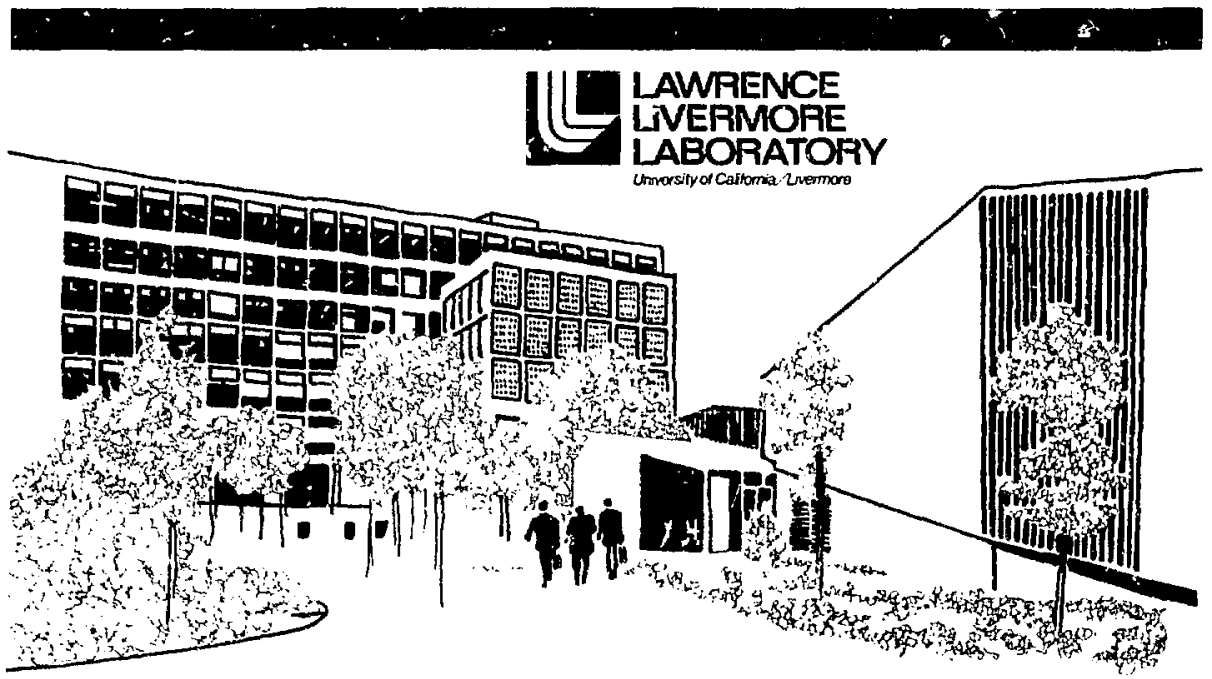




\section{NOTKCE}

Thls mport wa prepared an account of work eponsored by the Uniled Sules Governmens. Naither the Unitod States nos the United States Energy Reveurch a Deviopmenl Adminitintion, nor any of their emplayees, not any of their contractori, wbcontractons, or the's enployos, makes any wananty, exprew or implied, or aromes any tepl liabitity of teponsilitly for the sccuracy, completeness of usefulney of any Information, appsutus, product of ptocess disctoved, of represents thit tis ute wouls not isstinge Fitvatelyowned rehls.

\begin{tabular}{|c|c|c|}
\hline $\begin{array}{l}\text { Printed in the United S } \\
\text { Avalable from } \\
\text { National Teshnical Infor } \\
\text { U.S. Department of Cor } \\
\text { S285 Port Royal Road } \\
\text { Springfinld, VA 22161 } \\
\text { Price: Prined Copy S }\end{array}$ & $\begin{array}{l}\text { tates of Amer } \\
\text { mation Servo } \\
\text { gmerce }\end{array}$ & rea \\
\hline $\begin{array}{c}\text { Domentic } \\
\text { Price } \\
\end{array}$ & Powe Ranse & $\begin{array}{c}\text { Domestic } \\
\text { Prles }\end{array}$ \\
\hline S 3.50 & $326-350$ & 10.00 \\
\hline 4,00 & $351-375$ & 10.50 \\
\hline 4.50 & $376-460$ & 10.75 \\
\hline 5.00 & $401-425$ & 11.00 \\
\hline 5.50 & $426-450$ & 11.75 \\
\hline 6.00 & $45]-475$ & 12.00 \\
\hline 6.75 & $476-500$ & 12.50 \\
\hline 7.50 & $501-525$ & 12.75 \\
\hline 7.75 & $526-550$ & 13.00 \\
\hline 8.00 & $551-575$ & 13.50 \\
\hline 9.00 & $576-600$ & 13.75 \\
\hline 9.25 & $601-u p$ & - \\
\hline 9.7 & & \\
\hline
\end{tabular}

"Add 32.50 for each additional 100 page increment from 601 to 1,000 paget: add HASO for each additions I00 page ingetnent over 1,000 payes. 


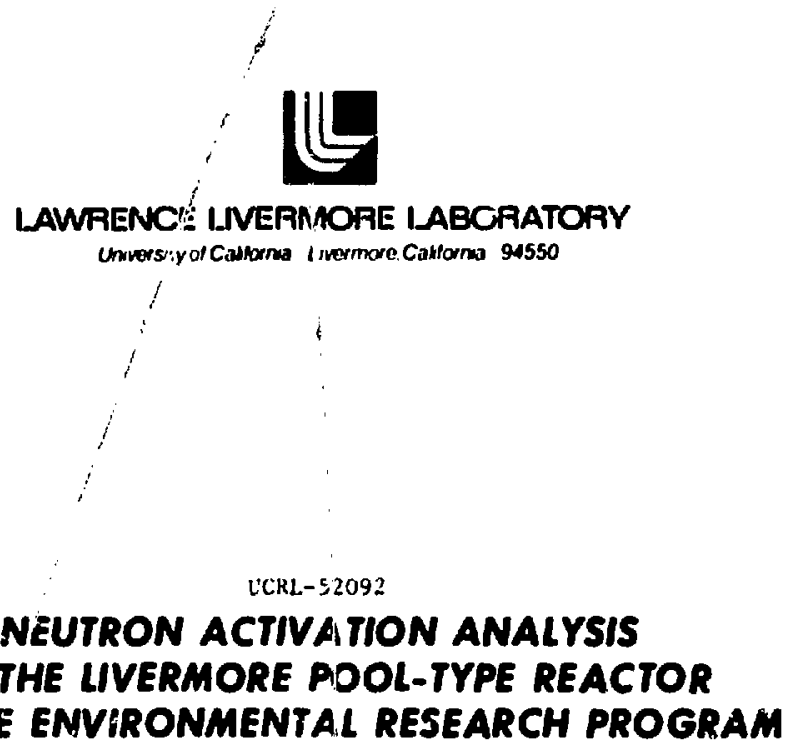

R. C. Ragatini

R. E. Heft

D. Garvis

MS. date: Juiy 2, 1976

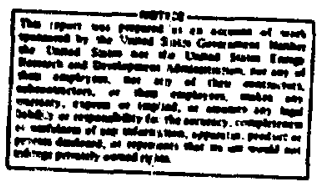




\section{NEUTRON ACTIVATION ANALYSIS AT THE LIVERMORE POOL-TYPE REACTOR FOR THE ENVIRONMENTAL RESEARCH PROGRAM}

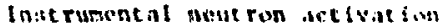

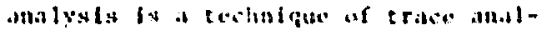

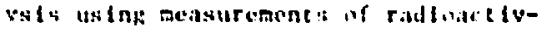
Ity induced in the sitaple lig exposure to a suurca at noutrons. The Induced



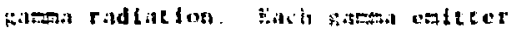

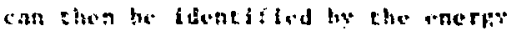

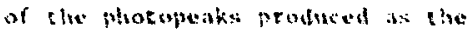


of the sout ronetnduced acetelty. $\alpha$

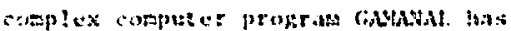



Abstract

\author{
anth: of nuellate fient frloat fon and

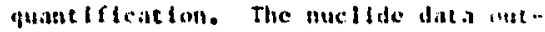 \\ put from lidusint. Ist procested by a

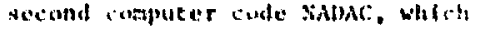 \\ develops olowatal abundance data \\ from distateprat fon rates wiserved. \\ the arefieds are those eaplinged at the \\ i.6remare Fool-type beactor in unp-

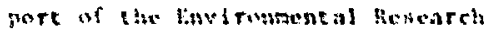 \\ froprag. dhonk the grocedure:t \\ dencribed and discussed are samplo

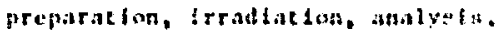 \\ and spplleaclon of the cechndinge.
}

\section{Introduction}

The purpose of Elts semart is to deserthe rise cupabilicles for erace

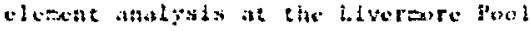

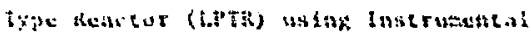


The cechulata and nethods ceploped are

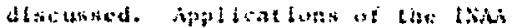

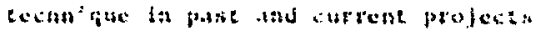

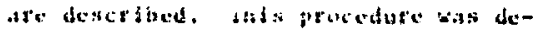

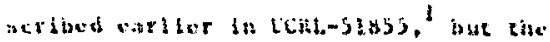



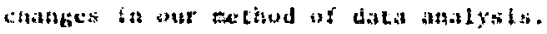

\section{Scope of Trace Element Analysis}

Trace-element aniagyis at the l,ptr has been primarily concerned with environmental rescarci programs.
Involvement oceurs at varlous level:" of Interactios, frotefindton of problenst through finished reports. 
In addition, a service is provided within the Laboratory for traceelement analysis. Users of the service are given as much assistance as desired. Applied research and development contracts are also carrled out with groups outside the l.aburatory.

Some areas of Investigation are:

- Trace elements in emissions from fossil fuel power generating plant.

- Trace elements in the environment of geothermal wells of the Impertal Valley.
- Trace elements in milk.

- Trace elements in aerosols.

- Nir sampling in the vicinity of smelting operations in Kellogg, Idaho.

- ACHEX (Californta Aerosol Characterization Experiment).

- Trace elements in environmental samples.

- Solls and sediments.

- Vegetation.

- Water - fresh and marine.

Some of these profects are described in the section on applications.

\section{Description of the Technique}

The INAA method of trace element Identiflcation has become Increasingly important with progressive improvement in sensit:vity. This improved sensitivity his been made posstble by highresnlution, solid-ssate radiation detectors, Improved data-collection and data-reduction techniques, and increased experience in samplepreparation and collection methods.

One of the chlef advantages of INAA is that it is usually a nondestructive analytical technique that requires little or no chemical pretreatment. It also permits measurement of 1sotopic concentrations as well as elemental concentrations for some 1sotopes. The word instrumental In this context meais that element or
Isotope tdentification is accomplished by instruments without the need for chemical separation.

Most INAA is done with thermal neutrons from a nuclear reactor. Neutron fluxes of $10^{12}$ to $10^{15} \mathrm{n} / \mathrm{cm}^{2} \mathrm{sec}$ are easily obtained at most reactor facil1ties. Those with fluxes of $10^{16}$ $\mathrm{n} / \mathrm{cm}^{2} \mathrm{sec}$ can be obtained at some of the pulsed research reactor faclitites. However, pulsed reactor fluxes are useful only when analyzing elements with Induced activitles having halt-lives on the order of tenths of seconds.

\section{BASIC PRINCIPLES}

Instrumental neutron activation analysis is based on the measurement 


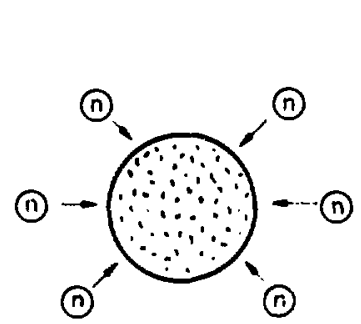

Specimen

in reactor



Decay of rodioactive isotopes

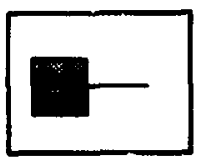

Ge (Li) detector

Fig. 1. Schematic diagram of Instrumental neutron activation analysis procedure.

af radinact lvity induced in the sample after exposure to a source of neutoons. This induced activity is determined most easily by detecting the emitted pamma radiation with a gamma snectrometer that characterlzes the emisstons. Thts characterization gives the energy and absolute intensily of each gamma ray. Figure 1 is a schematic representation of the method.

The mixture of nuclides that makes up the complex gamma spectrum must then be Identified. Each gamma emitter can be Identified by the energy (or energles) of the photopeaks produced as the nuclide decays towards its ground state and by the half-11fe of the neutroi-induced activity. Most elements that have a useful crosssection for neutron capture produce at least one isotope that can be used for a unique identification based on half-ilfe and ganma peaks. A complex computer program, GiMANAL, developed by Cunnink and Niday, accomplishes the major tasks of nuclide Identification and quantitation. This program (iAMNAL ${ }^{2}$ is discussed later.

The Identification of the nuclide in an activated sample does not immediacely yleld an elemencal analysis in a useful form. Information such as disintegrations per minute or atoms present at zero time must be translated into parts per million, total nanograms, etc. This can be accomplished in two ways. The first method is based on the application of known cross-section and radioactive decay relationships to calculate the disintegrations per minute per microgram that would be observed under the given Irradiation, cooling, and counting conditions. The second inethod is the simultaneous irradiation of a mixture 
of known amounts of the elements in question and determination of the unknown by direct ratio of activities. The procedure we use is primarily based on the first method given above. However In all cases one or more samples containing known amounts of specIf ic elements are included in the irradiation package. These samples are subjected to the same counting and analyais procedure as the unknown samples to ensure the accuracy of the derived results. The program MADAC," wich converts disintegration-rate data to elemental abundance data, is discussed below.

In most, if not all, samples competing activities must be considered. The samples usualiy contain many trace elements. The activation and counting schere must be chosen to optimize the' activicy of as many elements as reasonably possible. This usualiy requires two or more separate irradiations for each sample and various counting schedules depending on the type of sample and eiements to be analyzed. This is an effective method of utilizing the half-lives to scparate elements into groups, thereby reducing the complextty of the spectra and producing less ambiguous identification. In addition, strong incerference produced by a major component such as scdium can be allowed to decay, leaving the longer-lived trace elements sufficiently active for analysis. freeze-dried,
SAMPLE PREPARATION AND HANDLINC.

General

Sample preparation and handling are of great importance in trace element work. Clean techntques must be employed at every ntep prior to Irradiation. After the sumple ls actiyated, care can be relaxed since the sample is easlly differentlated from any contamination other chan radluactivity that might be introduced. The Insensitivity to handling procedures after Irradiaction is one of the most actractive features of activitton analysis. To maximize this arpantage, preltradidtion handlifä should be minimized.

If fissible, the sample should be transfered from its irradiation container into a counting concatner to eliminate the problem of subtracting the crace-element content of the irradiation container, If the sample is to be counted in its irradiation container or with a binder, the traceelement content must be determined from a statistically significant number of control containers or binder samplea. The same clean handling techniques nust be applied to the container or binder.

Samples may be either In solld or liquid form, solid being preferred. In general, liquid samples may require a concentration step before Irradiation. Liquids such as milk are 
Simple citometr:

beometry must be considiced in twe dspects: jrridiat lon and rounting. Ii sitme cases, the sime peometry will apple to both, namely when a disk shapu, which $j: s$ ideid for count lng, can be Irradiaced. When the sample cannot be irradiated in disk form, it mav be possible to approximate such a infigustian during. rounting by plarlns: a modered sample in a flat moethinleme envelupe, or a liquid in a $r: 1$ lndriral $: i: 1 !$.

Townimial: hatve been developed for preparinf: mot dry samples in a disk shape for irradiation with a hydraulis press. and appropriate dies. Some samnlen, sisch as fretede-dried skim milk, will mantain their stape after pressing wille uthers require some binder matorill. Binder: must be Leated as anv wher trace-olement content intreduced into the sample.

\section{l.iquid Samples:}

bhen I sample must be irradiated in liquid form, several precautions must be observed. Basically the problom is leakage of the sample from its container. There will be an increase in pressure in the contalner resulting from heating and radiolysis. Therefore space must be provided in the container for such a release of gas. Abouc one-half to two-thirds of the volume of the container should be available for expansion. Samples in plastic vials must be sealed by welding: those in quartz contalners are sealed by heat. The heat-sealed primary container must then be placed in a leak-prouf outer container. The l.PTR Lser's fiusde ${ }^{4}$ provides physical dimensions of most available outer contalners.

After irradiation the container is upened, and the liquid is cransferred to a counting vial. The sample can he counted in the irradiation container if counting geometry and container blank are taken into consideration.

\section{Solid Samples}

Solid samples have several advantages over liquid. The most important of these is the absence of leakage problems and the consequent relaxation of sealing requirements. These samples must still be held in a primary concainer that is closed tighty, but not necessarily sealed. There must be a secondary container as with liquids.

Another advantage is the ease of handling and the consequent reduced exposure of personnel to radiation. As stated before, the solid sample may be pressed into a disk shape. The disks are made in a variety of diameters, ranging from a quarter-inch to one inch. If binder is necessary, a known amount is added to the weighed sample. Powdercd polyethylene and 
Avice ${ }^{*}$ are two commerclaily avallable binders, Polyecinylene requires

heating to form a wafer jut does not require much pressure. Avicel requires no heat, but more prossure. Both materlals have acceptable hlanks for most analyses.

Solid samples Include parefcles suspended in air or other gases. Such particles are generally frradiated on the collection triedia. The blank for the collection media must be determined as for other materlals.

\section{Sample Size}

The size of sample varles with the type of sample, the matrix, and information desired. Experimental conditions often determine sample s!ze. For example, air sampling is limited by low concentrations of acrosol, sampling time, and capacity of the collection medium. In other cases, such as with milk, coal, soll, etc, enough sample might be avalialle to provide any size destred. The limiting factors are then the amount of radlation from the major constituents hat can be handled and counted, and the mixture of major and trace elements.

Thr range of sample sizes for ana-

\footnotetext{
* Reference to a company or product name does not imply approval or recommendation of the product by the University of California or the U.S. Energy Research â Development Administration to the excluston of others that may be suitable.
}

lyzing most solids ls irom $1.0 \mathrm{mp}$ to 1.0 ti. liquids san be handled in amounts close to $30 \mathrm{~m} 1$.

IRRADIATION ANH COLNTING PROCDDHRL:

The neutron sulurie for act l virt ion of samplins ls the t.PTK, whlch is moderated and cooled by licht wite? and consists of plate-type fut 1 eloments and horon-containing iont rol rusis located in a tank $7.9 \mathrm{~m}(26)(t)$ deep and $1.98 \mathrm{~m}(6.5 \mathrm{ft})$ in diameter. barfous beam tubes and Irradiation facilit hes allow arcest to neutron fluxes ranging as high as $7 \times 10^{13} \mathrm{n} / \mathrm{cm}^{2} \mathrm{sec}$. and gamma-dose rates above $10^{10} \mathrm{rad} /$ hr. The reactor ts used for basic and applied research in support of Laboratory programs. It is operated on a schedule that permits a routine maintenance pertod, standari safety system checks, and maximum operation for experiments and irradiations. The LPTR's User's Gulde ${ }^{4}$ descrlbes the experinental irradiation facilities and services that are available.

\section{Counting Schedule}

The counting schedules shown in Table 1 are typical for short and long Irradiations. The 10-min cociling time shown for the short irradiation is necessary since the detector systems used in the short analysis are not located at the reactor icself. Foilowing irradiation, samples are 


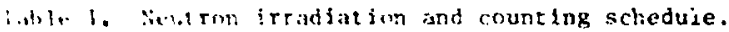

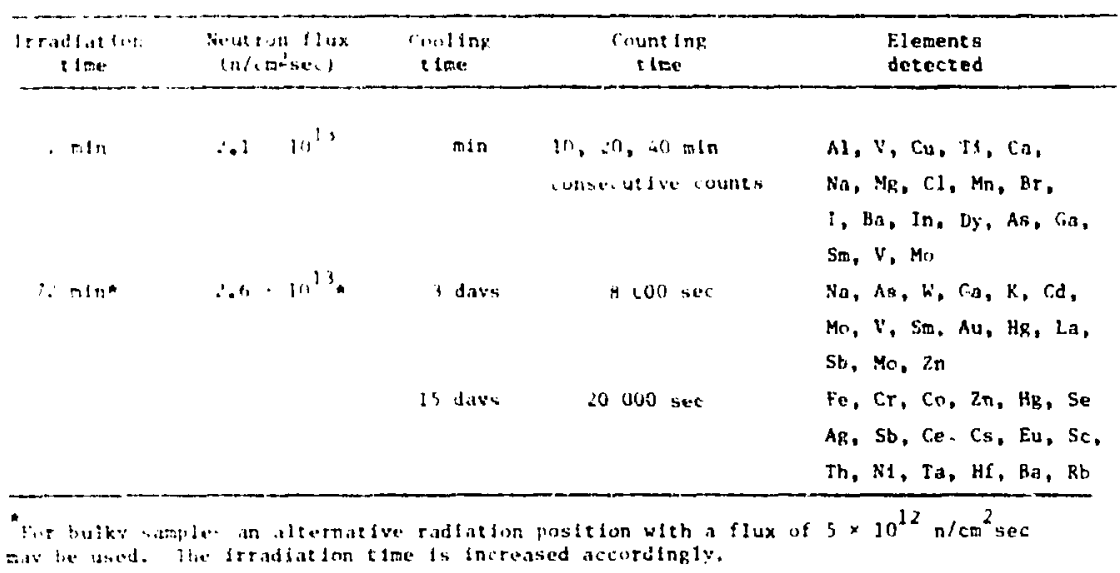

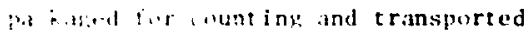
1. the . Nme ind tacilits within the in-rin wling periugt. The itradia-

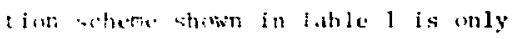
in example it varjuts suiemes that -1.12 bu there deperasing on the nature at the elemental information desired. lili: schome frovides a relistvely complete anatvis with a mintmum amount of dotentur time.

Tixe number of detector systems avilable tor the neutron-activation pringram varles but usually is in the range of 10 to 12 systems. All systems are calibrated to operate undar che CAMANAL resolution and analysis metir,d. Five of the systems are automated. The automated systems, interfaced to a PDP-8 computer, can handle 16 samples/system thus allowing 24-hr/da counter use. The remalnder of the sustems can analyze one sample at a time, and the data are transferred to the PDP-8 systen by a manual dump. All data are subsequently transferred to magneic tape and analyzed on a cuC-6600 computer (described below).

Figure 2 shows a typical sample changer wîh a Ge(Li) detec:or system. The cryostat and detector are seen to the left of upper center, the sampte holdes's in the changer are in the lower half, and the mechanism f:r ralsing a sample Into counting position is at the center of the photograph. The wiole system is automated under control of the PDP- 8 system.

The data obtalned from the counting scheme shown In Table 1 are recorded on computer-compatible magnetic tape 
for permanent reference and for subsequent reduction and analysis.

Two libraries of photopeak abundances and half-lives are used. The library for short-1rradiation analyses contains nuclides whose halflives range from $2 \mathrm{~min}$ to about 1 da. The 75 nuclides in this library include all candidates for activation having cross-sections greater than about $0.05 \mathrm{~b}$. The library for analysis of long irradiation spectra consiats of 108 nuclides whose half- lives exceed about 1. hr. The criteria for inclusion are again based on cross-section. The total library listing of nuclide half-lives and photopeak abundances is too long to include in this report. A partial listing, giving only the major abundance photons for the more commonly found nuclides is given in Table 2 . The table shows that ${ }^{65} \mathrm{Zn}$ has a gamma ray with an energy of $1115.4 \mathrm{keV}$. Thus, if there are large anounts of both $\mathrm{Zn}$ and Sc in a sample it may not

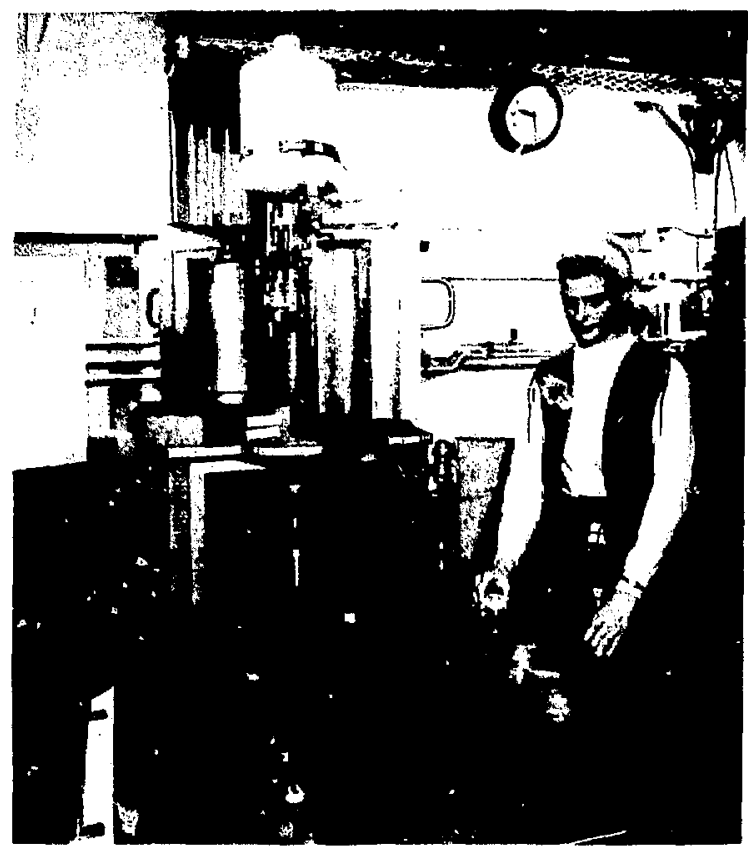

Fig. 2. Radiochemistry Division automatic sample changing system utilizing a Ge(Li) detector. 
Table 2. Parent, daughter, half-life, and energy of observed ganma ray's for elements analyzed by INAA at the LPTR.

\begin{tabular}{|c|c|c|c|}
\hline $\begin{array}{l}\text { Parent } \\
\text { element } \\
\text { exposed }\end{array}$ & $\begin{array}{l}\text { Daughter } \\
\text { isotope } \\
\text { observed }\end{array}$ & Half-life & Gamma-ray $\underset{\text { energy observed }}{\text { (keV) }}$ \\
\hline $\mathrm{Ti}$ & $21^{51}$ & 5.79 min & $320.0(100)$ \\
\hline $\mathrm{Mg}$ & ${ }_{12}^{27} \mathrm{Mg}$ & $9.46 \mathrm{~min}$ & $843.8(100), 1014.5(37.5)$ \\
\hline $\mathrm{Cu}$ & ${ }_{29}^{66} \mathrm{Cu}$ & $5.10 \mathrm{~min}$ & $1039.2(100)$ \\
\hline V & $23 \mathrm{~V}$ & $3.75 \mathrm{~min}$ & $1434.3(100)$ \\
\hline A1 & ${ }_{13}^{28} \mathrm{~A} 1$ & $2.32 \mathrm{~min}$ & $1778.7(100)$ \\
\hline $\mathrm{Ca}$ & ${ }_{20}^{49} \mathrm{Ca}$ & $8.80 \mathrm{~min}$ & $3084.4(100)$ \\
\hline $\mathrm{Ba}$ & ${ }_{56}^{139} \mathrm{Ba}$ & $82.9 \min$ & $165.8(100)$ \\
\hline $\mathbf{I}$ & ${ }_{53}^{128} \mathrm{I}$ & $25.0 \mathrm{~min}$ & $443.3(100), 526.4(9.9)$ \\
\hline $\mathrm{Br}$ & ${ }_{35}^{80} \mathrm{Br}$ & $16.8 \mathrm{~min}$ & $616.2(100), 665.6(17.2)$ \\
\hline In & ${ }_{49}^{116} \mathrm{In}$ & $53.7 \mathrm{~min}$ & $417.0(40.2), 1097.1(59.8), 1293.4(100)$ \\
\hline $\mathrm{Na}$ & $11^{24} \mathrm{Na}$ & $15.0 \mathrm{hr}$ & $1368.4(100), 2754.1(100)$ \\
\hline $\mathrm{Cl}$ & $\begin{array}{l}38 \\
17^{\mathrm{C} 1}\end{array}$ & $37.3 \mathrm{~min}$ & $1642.7(74.5,2167.6(100)$ \\
\hline Mn & $25^{56}$ & $155.0 \mathrm{~min}$ & $846.7(100), 1811.2(29.4)$ \\
\hline As & ${ }_{33}^{76}{ }^{A s}$ & $26.4 \mathrm{hr}$ & $559.1(100), 657.1(100)$ \\
\hline$W$ & ${ }^{187} \mathrm{~W}$ & $23.9 \mathrm{hr}$ & $\begin{array}{l}134.2(32.6), 479.5(83.1), 618.2(23.1), \\
\quad 685.7(100)\end{array}$ \\
\hline $\mathrm{Ga}$ & ${ }_{31}^{72} \mathrm{Ga}$ & $14.1 \mathrm{hr}$ & $629.9(25.5), 834.0(100), 2201.6(27.3)$ \\
\hline $\mathrm{K}$ & $\begin{array}{l}42 \\
19^{K}\end{array}$ & $12.4 \mathrm{hr}$ & $\begin{array}{l}1524.7(100) \\
-9-\end{array}$ \\
\hline
\end{tabular}


Table 2, (Continued)

\begin{tabular}{|c|c|c|c|}
\hline $\begin{array}{l}\text { Parent } \\
\text { element. } \\
\text { exposed }\end{array}$ & $\begin{array}{l}\text { Daughter } \\
\text { Isotope } \\
\text { observed }\end{array}$ & Half-life & $\begin{array}{l}\text { Gauma-ray energy observed }{ }^{a} \\
\text { (kev) }\end{array}$ \\
\hline $\mathrm{cd}$ & ${ }_{48}^{115} \mathrm{Cd}$ & $53.5 \mathrm{hr}$ & $492.3(29.5), 527.9(100)$ \\
\hline $\mathrm{Sm}$ & ${ }_{62}^{133} \mathrm{Sm}$ & $46.8 \mathrm{hr}$ & $103.2(100)$ \\
\hline Au & ${ }_{79}^{198} \mathrm{Au}$ & $64.7 \mathrm{hr}$ & $411.8(100)$ \\
\hline La & $57^{14 a}$ & $40.2 \mathrm{hr}$ & $328.8(21.4), 487.0(44.4), 1596.6(100)$ \\
\hline Fe & ${ }_{26}^{59} \mathrm{Fe}$ & $45.6 \mathrm{da}$ & $1059.3(100), 1291.5(77.0)$ \\
\hline $\mathrm{Cr}$ & ${ }_{24}^{51} \mathrm{Cr}$ & $27.8 \mathrm{da}$ & $320.1(100)$ \\
\hline $\mathrm{Co}$ & ${ }_{27}^{60} \mathrm{Co}$ & $5.26 \mathrm{yr}$ & $1173.2(100) 1332.5(100)$ \\
\hline $\mathbf{2 u}$ & $30^{65}$ & $24.3 \mathrm{da}$ & $1115.5(100)$ \\
\hline $\mathrm{Hg}$ & ${ }_{80}^{203} \mathrm{Hg}$ & $46.9 \mathrm{da}$ & $279.2(100)$ \\
\hline Sc & $34^{75} \mathrm{Sc}$ & 120. da & $136.0(96.0), 264.7(100)$ \\
\hline $\mathrm{Ag}$ & ${ }_{47}^{108 \mathrm{~m}} \mathrm{Ag}$ & $5.00 \mathrm{yr}$ & $434.0(100), 614.4(100), 723.0(100)$ \\
\hline Ag & ${ }_{47}^{110 \mathrm{~m}} \mathrm{Ag}$ & 255. da & $\begin{array}{l}657.7(100), 884.7(79.6), 937.5(36.5), \\
1384.2(27.7)\end{array}$ \\
\hline Sb & ${ }_{51}^{124} \mathrm{Sb}$ & $60.3 \mathrm{da}$ & $602.7(100), 1691.1(53.2)$ \\
\hline $\mathrm{Ce}$ & ${ }_{58}^{141} \mathrm{Ce}$ & $32.5 \mathrm{da}$ & $145.5(100)$ \\
\hline Eu & ${ }_{63}^{152} \mathrm{Eu}$ & $12.7 \mathrm{yr}$ & $121.8(100), 344.2(85.6), 1408.1(65.0)$ \\
\hline $\mathrm{Sc}$ & ${ }_{21}^{46} \mathrm{Sc}$ & $83.9 \mathrm{da}$ & $889.3(100), 1120.5(100)$ \\
\hline Th & ${ }_{91}^{233} \mathrm{~Pa}$ & $27.0 \mathrm{da}$ & $\begin{array}{l}311.9(100) \\
-10-\end{array}$ \\
\hline
\end{tabular}


Table 2. (Continued)

\begin{tabular}{|c|c|c|c|}
\hline $\begin{array}{l}\text { Parent } \\
\text { element } \\
\text { exposed }\end{array}$ & $\begin{array}{l}\text { Daughter } \\
\text { isotope } \\
\text { observed }\end{array}$ & Half-life & $\begin{array}{c}\text { Gamma-ray energy observed } \\
(\mathrm{keV})\end{array}$ \\
\hline $\mathrm{Ni}$ & $27^{58} \mathrm{Co}$ & $71.3 \mathrm{da}$ & $811.1(100)$ \\
\hline HF & ${ }_{72}^{1.75} \mathrm{Hf}$ & $10.0 \mathrm{da}$ & $343.4(100)$ \\
\hline HF & ${ }_{72}^{181} \mathrm{Hf}$ & $42.3 \mathrm{da}$ & $133.1(49.4), 482.2(100)$ \\
\hline$U$ & ${ }_{92}^{239} \mathrm{U}$ & $23.5 \mathrm{~min}$ & $76.67(59.3)$ \\
\hline $\mathrm{U}$ & ${ }_{93}^{239} \mathrm{~Np}$ & $2.353 \mathrm{da}$ & $\begin{array}{l}99.4(12.3,103.5(19.6), 106.1(25.2), \\
228,1(11.0)\end{array}$ \\
\hline
\end{tabular}

\footnotetext{
Numbers given in parentheses following the gamma ray energy are the relative intensities (\%) of the gamma rays. Only higher abundance gammas are Included in this table.
}

be poasible to separate the gamma-ray peaks because of overlap. Detectors that are currently available do not have adequate resolutions to separate these peaks. Scandfum has another gamma ray with an energy of $889.4 \mathrm{keV}$, and the only appreciable interference with this peak is the $110 \mathrm{~m}$ Ag gamma ray at $884.7 \mathrm{keV}$. By the use of the GAMANAL program, it is possible to resolve large amounts of $110 \mathrm{~m} \mathrm{Ag}$, ${ }^{46} \mathrm{Sc}$, and ${ }^{65} \mathrm{Zn}$ in the same sample. A close examination of Table 2 reveals several other interferences of the type discussed above that occur in a typical sample.
Typical output from Instrumental Neutron Activation Analysis Sample

A typical high-volume, air-filter, aerosol sample is shown as an example of gamma spectra obtained after activation. Figures 3 through 7 are plots of the data for our filter sample $21 \mathrm{~A}$ resulting from the irradiation and counting periods for the analyses of these particular samples.

\section{DATA REDUCTION}

The gamma-spectrometric data produced by the detector systems are processed first by GAMANAL. The output 


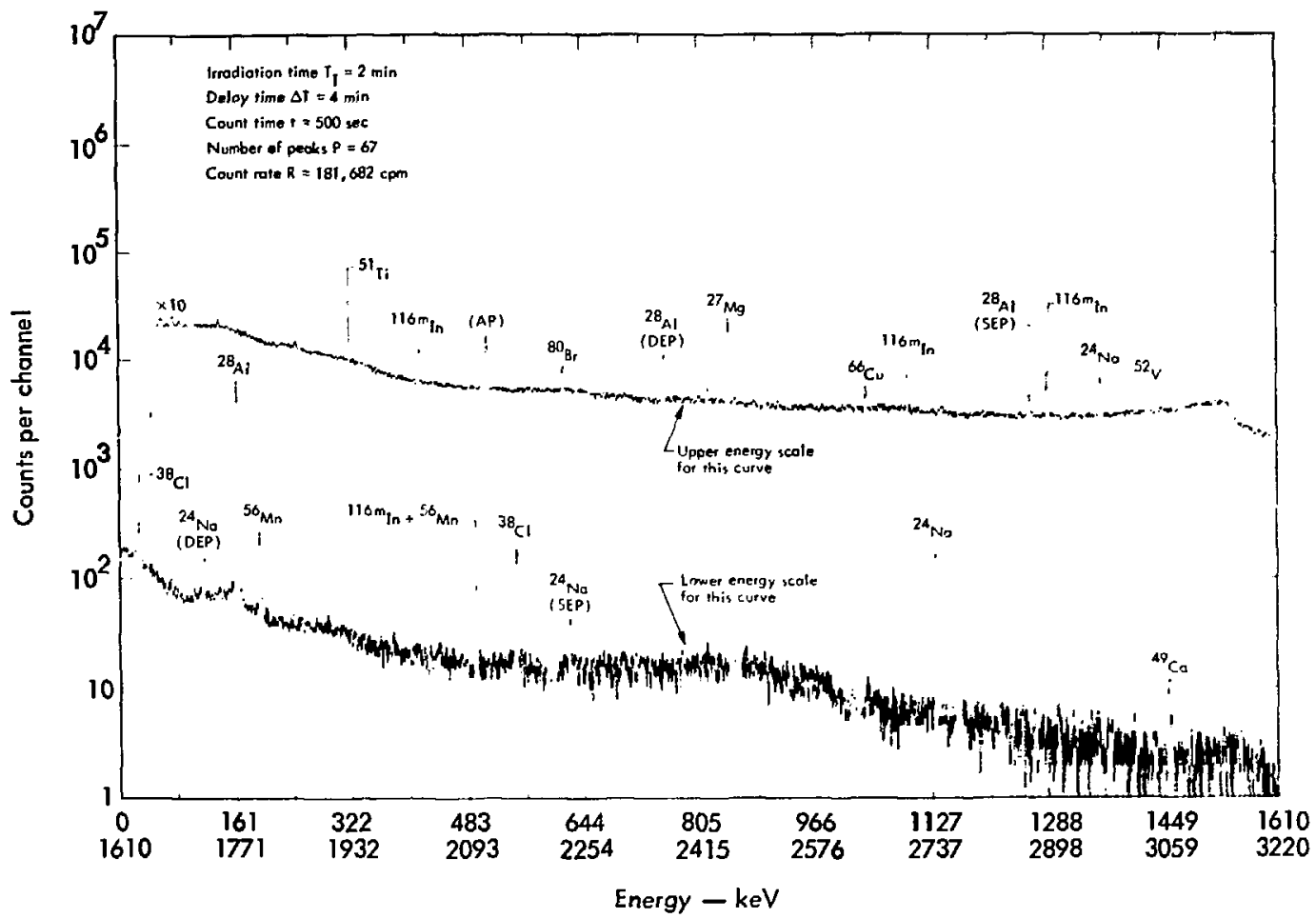

Fig. 3. INAA spectrum Q1 for high-volume air filter sample IAS-21A. Sample data: total airflow through filter $958 \mathrm{~m}^{3}$; mass loading, of air as indicated by material trapped in filter, $226 \mu \mathrm{g} / \mathrm{m}^{3}$. SEP = single escape peak, HP = double escape peak, AP = annihilation peak. 


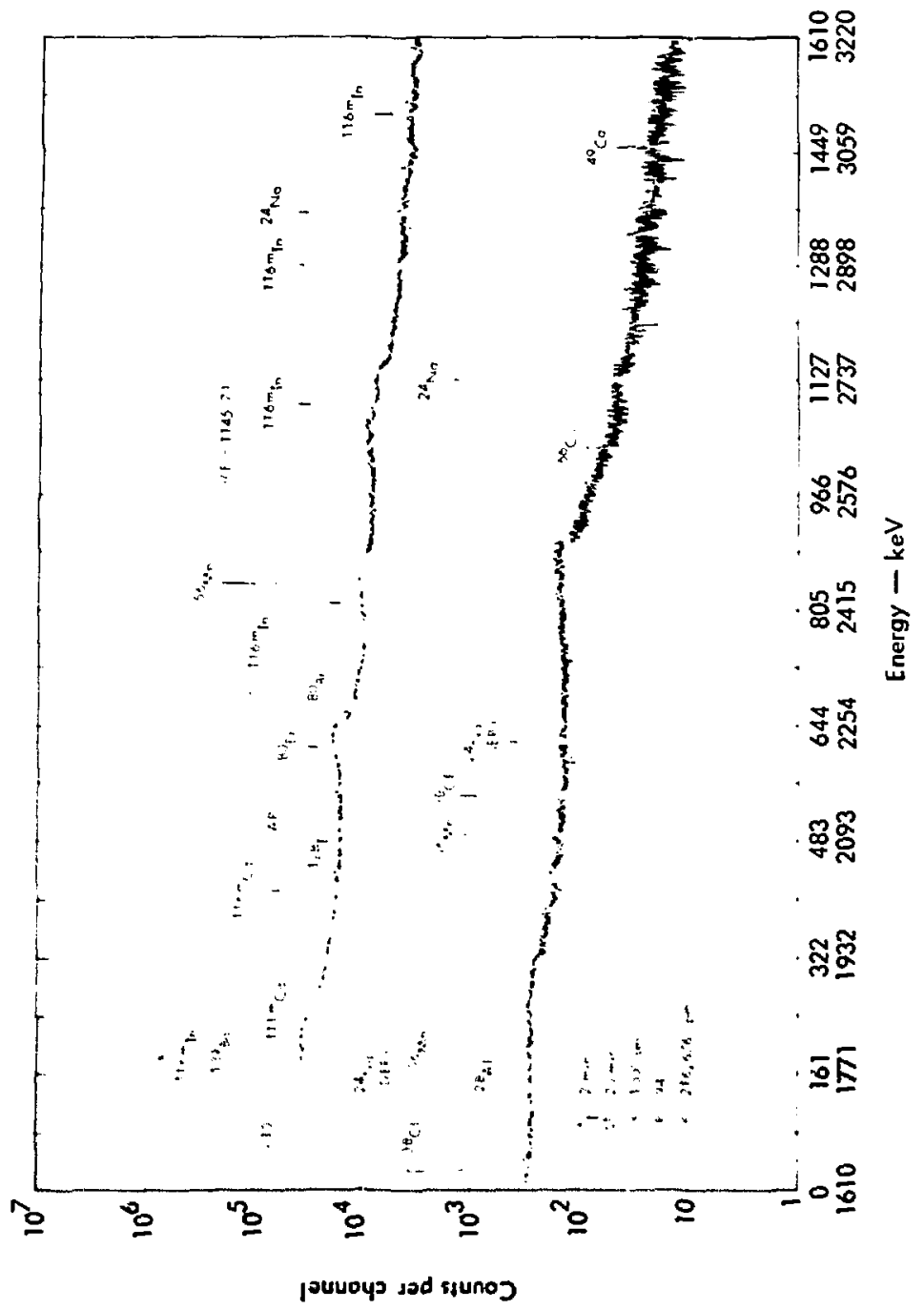

है

是

品

5
5
5

穿

$\stackrel{5}{=}$

$\frac{1}{6}$

0
$\frac{1}{5}$
5
$\frac{1}{5}$
$=$

s

8

恶点

$\div$

is 


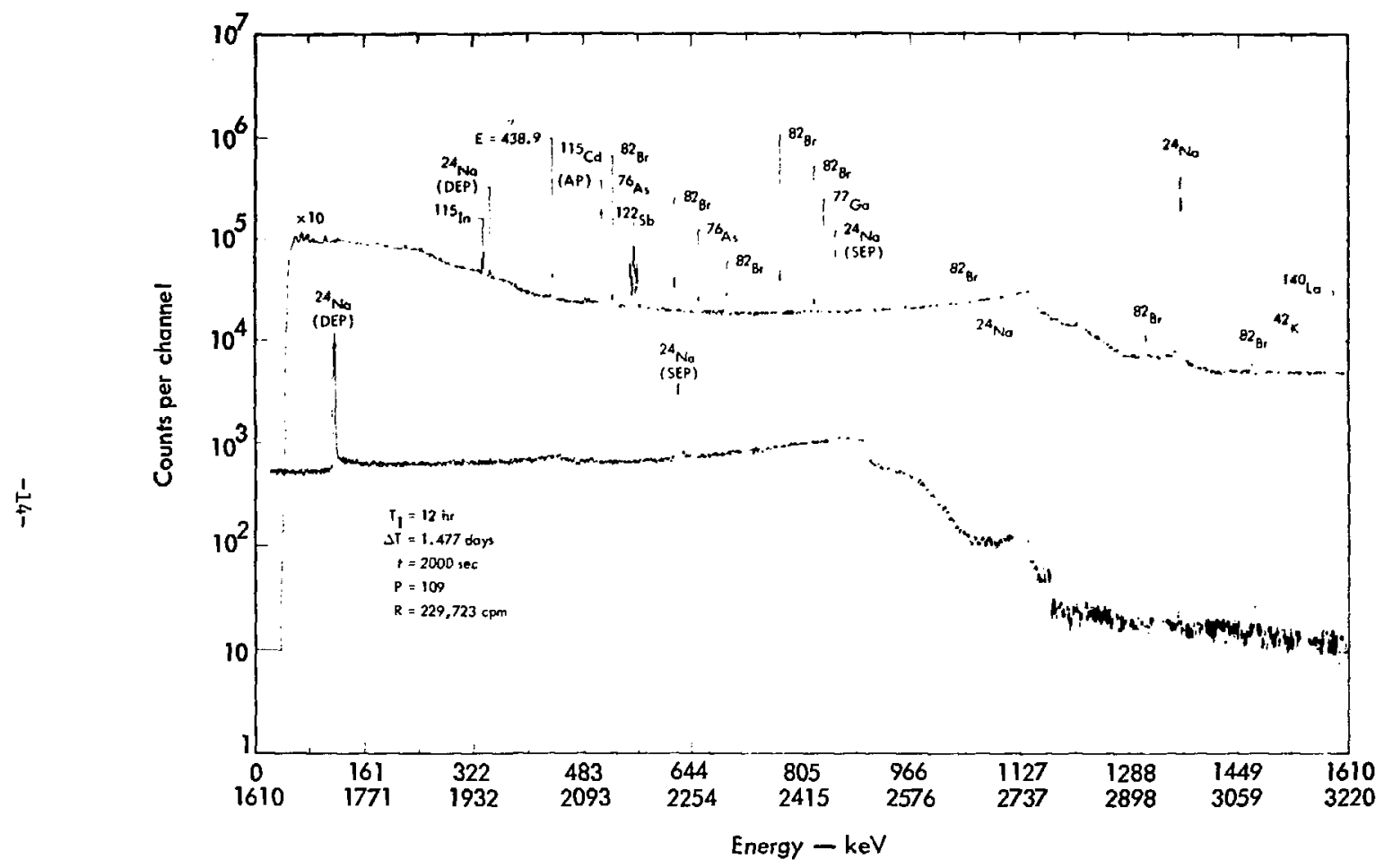

Fig. 5. INAA spectrum Ll for high-volume air filter sample IAS-21A, (Sample data and abbreviations same as Fig. 3.) 


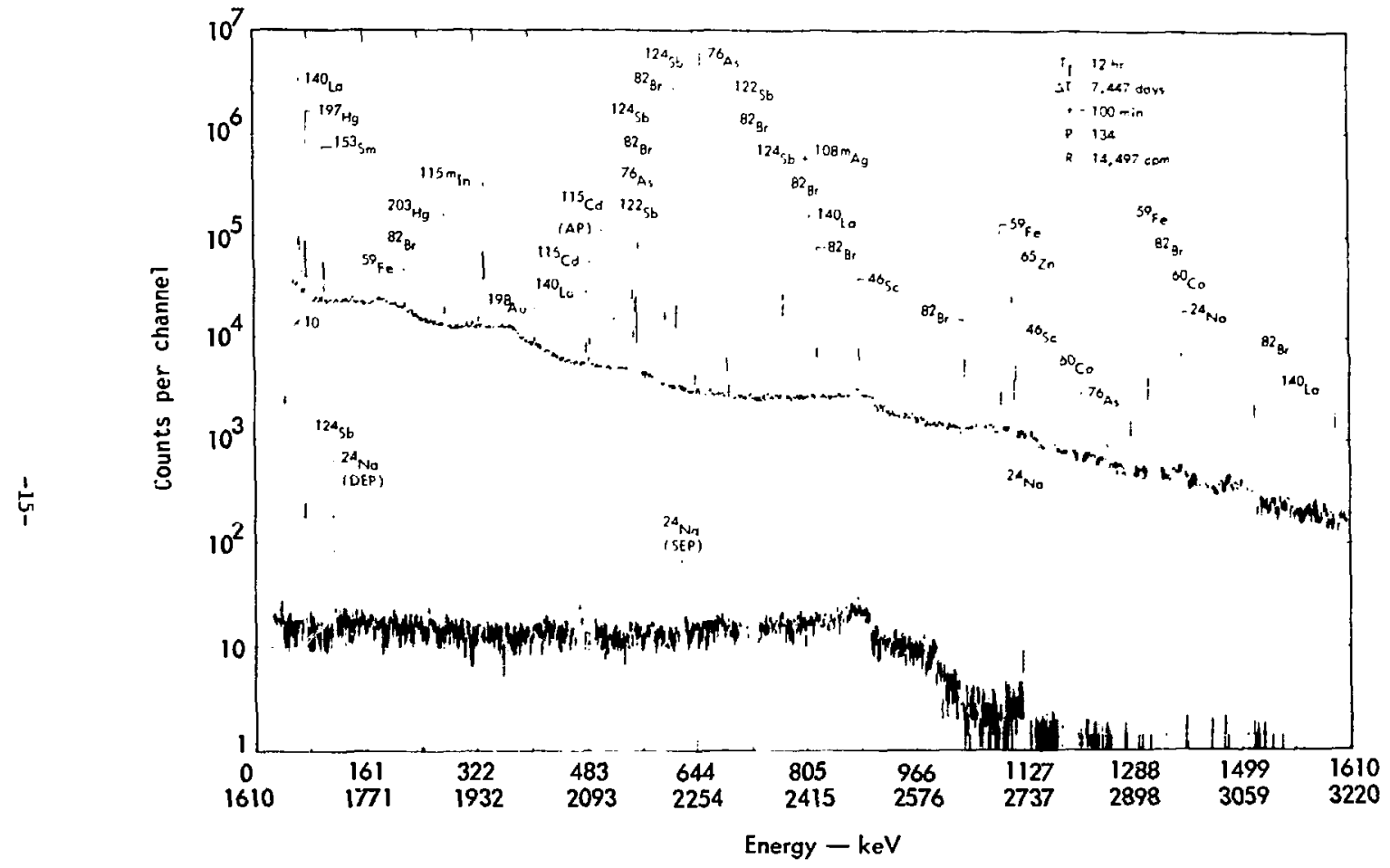

Fig. 6. INAA spectrum L2 for high-volume air filter sample IAS-21A. (Sample data and abbreviations same as Fig. 3.) 




Fig. 7. INAA spectrum L3 for high-volume air filter sample IAS-21A. (Sample data and abbreviations same as $F 1 g=3$. ) 
of GAMNAL (consisting of one card per nuclide for each spectrometric analysis) serves as Input to NADAC. The NADAC program reduces these data to micrograms of element for each element on a sample-by-sample basis.

\section{Description of GAMANAL}

The GAMANAL code is a general purpose computer program for data reduction and Interpretation of gamma spectra. It examines the pulse-height data for background and peak regions, fits these peaks with the proper shape functions, and corrects for the effects of geomecry, attenuation, and detector efficiency in evaluating the photon-emission rate. The program then searches a library of decayscheme information and makes tentative assignments for each of the observed peaks. A matrix of equations is formed so that the iutensity of each peak is described as a linear addition of the identifled nuclides. The quantitative value, as well as the degree of interference, is the result of a least-squares solution of this set of equations. Unlikely components are also eliminated in this process. A more complete description is given by Gunnink and Niday. 2

\section{Description of NADAC}

For each nuclide in a sample, NADAC calculates the expected disintegration race per microgram of element at counting time. The tocal micrograms of element for each nuclide detected is calculated by dividing the disintegration rate found by GAMANAL by the expected rate calculated by NADAC for the irradiation, cooling, and counting times for the sample. When the sample is counted more than once, the total micrograms calculated for each count are combined according to a weighting factor that corresponds to the inverse square of the standard deviations for the separate counts. The weighted mean for the total micrograms of each element is corrected first for interfering production of the measured nuclide by an alternate reaction $\left(\mathrm{e} . \mathrm{g} \cdot{ }^{27} \mathrm{Al}(\mathrm{n}, \mathrm{p}){ }^{27} \mathrm{Mg}\right.$ interferes with $\left.{ }^{26} \mathrm{Mg}(n, \gamma){ }^{27} \mathrm{Mg}\right)$ and second for contribution to the observed totai micrograms by mounting or sample containment materials that were irradiated and counted with the sample. In addition to providing for interference and blank correction, NADAC also provides for correctly calculating total micrograms when:

- Counting time is long compared to half-life of nuclide.

- Sample was subjected to multiple or interrupted irradiations.

- Nuclide counted is daughter of nuclide produced, including the case where the daughter nuclide has some independent production.

The physical parameters used in the MADAC calculation are the half-lives 
of the parent and daughter, the correction for blanks, the rate of production of nuclide per microgram of element, and the rate of production of suclide per microgram of element, giving the interfering reaction. I'he half-Iife data are the same as those used in GAMANAL and represent best values either measured at LLL or taken from the 1iterature. The elemental abundances in the blank are determined from separate irradiations of multiple samples. The rate of production of nuclide by reactions yielding $n, p$ interferences is determined by irradiating a known quantity of the element producing the interference in each region of the reactor used. The rate of production of those nuclides by $n, \gamma$ or $n$ fission reactions can be calculated $i^{i}$ the following are known:

- Thermal neutron cross-section $\sigma_{\text {th }}(b)$.

- Resonance integral RI (b).

- Thermal neutron flux $\Phi_{T H}$ (n/ $\left.\mathrm{cm}^{2} \mathrm{sec}\right)$.

- Epithermal neutron flux $\Phi_{E P I}$ $\left(\mathrm{n} / \mathrm{cm}^{2} \mathrm{sec}\right)$.

- Atomic mass of the element M (g).

- Isotope abundance of the nuclide $G(\xi)$.

Where the production rate of the nuclide $R$ is expressed in units of atoms/min. $\mu_{g}$ the following relationship is used:

$R=\frac{3.614 \times 10^{6} \mathrm{G}\left(\phi_{\mathrm{TH}} \sigma_{\mathrm{TH}}+\phi_{\mathrm{EPI}} \mathrm{RI}\right)}{\mathrm{M}}$
The constant factor $3.614 \times 10^{6} \mathrm{In}$ cludes a flux factor of $1 \times 10^{13}$ $\mathrm{n} / \mathrm{cm}^{2} \mathrm{sec}$. Hence $\Phi_{T H}$ and $\Phi_{\mathrm{FPI}}$ in the above expression are fluxes expressed in units of $10^{13} \mathrm{n} / \mathrm{cm}^{2} \mathrm{sec}$. Thus if the thetmal FIux were $2.5 \times 10^{13}$ the numerical value of $\phi_{T H}$ would be 2.5 .

$R=\frac{\left(3.614 \times 10^{6}\right)\left(\mathrm{C} * \mathrm{TH}^{\circ} \mathrm{TH}\right)\left[1+\left(\frac{\mathrm{EPI}^{*}}{\mathrm{TH}}\right)\left(\frac{\mathrm{RI}}{\mathrm{THH}_{\mathrm{H}}}\right)\right]}{M}$.

The ratio of epithermal to themal flux can be determined for a particular reactor region efther from the cadlum ratio for the region or by simultaneous irradiation of two nuclides having widely different RI $/ \sigma_{T H}$ values and well-known thermal cross-sections. For the LPTR reactor, the flux ratio in the $5-2$ Irradiation facility is 0.0208; and in both the E-1 facility and the slow rabblt it is 0.0450 . While these may seem to be small correction terms in themselves, when taken with the rat lo of the resonance integral to thermal cross-section, they may produce a very signiftcant deviation from pure thermal neutron production rates. Values of $\mathrm{RI} / \sigma_{\mathrm{TH}}$ for the nuclides in the GAMNAL libraries range from 0.46 for ${ }^{46}$ Sc to 102.9 for ${ }^{239} \mathrm{U}$. Thus for ${ }^{239} \mathrm{U}$ (and $239 \mathrm{~Np}$ ) the actual rate of production Is higher than that for a pure thermal neutron flux by a factor of 3.14 in the S-2 racility and by a factor of 5.63 in $E-1$ and slow rabbit factifties. 
Tabulations of $\sigma_{\mathrm{TH}}$ and RI values are given by $R$. Sher ${ }^{5}$ and $H$. Albinsson ${ }^{6}$ In the IAEA Hondbook of Nuclear Activation Cross-3ections. A discussion of multielement determination of $\Phi_{\text {EPI }} / \Phi_{\mathrm{TH}}$ as well as a compilation of $\mathrm{RI} / \sigma_{\mathrm{TH}}$ values is given by Van Der Linden, De Corte, and Hoste ${ }^{7}$ in Vol. II of Nuclear Data in Science and Techrologi, Further data on RI and $\sigma_{\text {TH }}$ measurement that postdate those cited by Sher and Albinsson are reported by G. Gleason. 8

Equation (2) above may be expressed as a product of two terms:

$$
R=\Phi_{T H} R_{0}
$$

where

$\mathrm{k}_{0}=3.614 \times 10^{4} \mathrm{G} \sigma_{\mathrm{TH}}\left[1+\left(\frac{\phi_{\mathrm{EPI}}}{\sigma_{\mathrm{TI}}}\right)\left(\frac{\mathrm{RI}}{\sigma_{\mathrm{TH}}}\right)\right]$

Is the rate of production of a themal neutron flux of $1 \times 10^{13} \mathrm{n} / \mathrm{cm}^{2}$ sec. values of $k_{0}$ for the individual nuclides are entered into NADAC as a table of stored constants for each of the reactor irradiation facllities. The value of ${ }^{\mathrm{T}} \mathrm{H}$, which is the thermal neutron flux expressed in units of $10^{13} \mathrm{n} / \mathrm{cm}^{2} \mathrm{sec}$, is determined for Individual samples by concurrent irradiation of flux monitors. A flux montror can be any element for which a kuowil number of micrograms is irradiated. The value for \$ 17 is simply the ratio of micrograms calculated assuming a flux of $1 \times 10^{13}$ to micrograms actuaily present in the monitor. A detalled description of the NADAC code and its mathematical bas is is given by Heft and Martin. ${ }^{3}$

\section{Standard1zat 1on}

The foregoing discussion of the Jetermination of micrograms of an element by NADAC was given in terms of theoretical application of the Iiterature values of thermal crosssections and resonance integral. The actual application modifles these values based on the results obtalned by irradiation of standard samples containing known amounts of the elements. Where the calculated amount of element differs from the standards, the rate constant $R$ is adjusted to give the correct answer. For most nuclides whose literature values for $\sigma_{\text {Th }}$ and RI appear to be adequately determined, the calculated $k$ value and the literature value are within a few percent. For a few nuclides (e.g., ${ }^{115} \mathrm{Cd},{ }^{169} \mathrm{Yb},{ }^{175} \mathrm{Yb}$ ) a significant difference exists between calculated and literature values. For some of the less common elements (e.g., Er, Ho, Ir) where suitable standard soluthons of the elements are not aval1able, the literature values for the cross-sections are used. An ongoing program of atandardization based on the assay of elemental scandards is being carried our. The results of 
this program will be published upon its completion.

\section{DETECTION LINITS}

Theoretical detection limits for 75 elements given in Table 3 are based on a maximum irradiation time of $1 \mathrm{hr}$, a thermal neutron flux of $10^{.13} \mathrm{n} / \mathrm{cm}^{2} \mathrm{sec}$, and no apprectable interferences. 9 These detection limits can therefore be considered as theoretical limits within the srate-of-the-art for analysis of the pure element.
For samples containing a mixture of elements, the detection 1 imits vary greatly depending on the nature of the principal consticuents and on the contribution to the blank by other materials contained in the sample. An extreme case of limited detection would occur if one attempted to measure short-1ived trace contrminants in a sample of dysprosium oxide. An example of detection ifmits including Iimitations imposed by matrix and mounting materials is shown in Table 4.10

Table 3. Theoretical detection limits of the INAA technique to 75 elements, assuming a $1-\mathrm{hr}$ irradiation with a thermal neution flux of $1013 \mathrm{n} / \mathrm{cm}^{2} \mathrm{sec}$ and no appreciable interferences.

\begin{tabular}{ll}
\hline $\begin{array}{l}\text { Limit of detection } \\
(\mu \mathrm{gg})\end{array}$ & Dy \\
\hline $1.3 \times 10^{-7}$ & $\mathrm{Eu}$ \\
$4.9 \times 10^{-7}$ & - \\
$1.3 \times 10^{-6}$ & $\mathrm{Mn}, \mathrm{In}, \mathrm{Lu}$ \\
$4.9 \times 10^{-6}$ & $\mathrm{Co}, \mathrm{Rh}, \mathrm{Ir}$ \\
$1.3 \times 10^{-5}$ & $\mathrm{Br}, \mathrm{Sm}, \mathrm{Ho}, \mathrm{Re}, \mathrm{Au}$ \\
$4.9 \times 10^{-5}$ & $\mathrm{Ar}, \mathrm{V}, \mathrm{Cr}, \mathrm{Gr}, \mathrm{As}, \mathrm{Pd}, \mathrm{Ag}, \mathrm{I}, \mathrm{Pr}, \mathrm{W}$ \\
$1.3 \times 10^{-4}$ & $\mathrm{Na}, \mathrm{Ge}, \mathrm{Sr}, \mathrm{Nb}, \mathrm{Sb}, \mathrm{Cs}, \mathrm{La}, \mathrm{Er}, \mathrm{Yb}, \mathrm{J}$ \\
$4.9 \times 10^{-4}$ & $\mathrm{Al}, \mathrm{Cl}, \mathrm{K}, \mathrm{Sc}, \mathrm{Se}, \mathrm{Kr}, \mathrm{Y}, \mathrm{Ru}, \mathrm{Gd}, \mathrm{Tm}, \mathrm{Hg}$ \\
$1.3 \times 10^{-3}$ & $\mathrm{Si}, \mathrm{Ni}, \mathrm{Nb}, \mathrm{Cd}, \mathrm{Te}, \mathrm{Ba}, \mathrm{Tb}, \mathrm{HF}, \mathrm{Ta}, \mathrm{Os}, \mathrm{Pt}, \mathrm{Th}$ \\
$4.9 \times 10^{-3}$ & $\mathrm{P}, \mathrm{Ti}, \mathrm{Zn}, \mathrm{Mo}, \mathrm{Sn}, \mathrm{Xe}, \mathrm{Ce}, \mathrm{Nd}$ \\
$1.3 \times 10^{-2}$ & $\mathrm{Mg}, \mathrm{Ca}, \mathrm{Tl}, \mathrm{Br}$ \\
$4.9 \times 10^{-2}$ & $\mathrm{~F}, \mathrm{Cr}, \mathrm{Zr}$ \\
$1.3 \times 10^{-1}$ & $\mathrm{Ne}$ \\
$4.9 \times 10^{-1}$ & $\mathrm{~S}, \mathrm{~Pb}$ \\
1.3 & $\mathrm{Fe}$
\end{tabular}




\section{LIDATLON}

To verify the accuracy of the INAA procedure that is described acove, duplicate sumples of the National Bureau of Standards siandard reference materials Coal (SRM 1632) and Flyash (SRM 1633) wete tyecd and Lhis: resulta compared with elemental concentration for those materials reported by NBS and by ondov et al. ${ }^{11}$ The data of Ondov et al. are based on multiple analyses of these standard reference materials by a sroup of independent laboratcries. (The group included LLL; however, the earlier I.LL results were obtained by an INAA procedure based on concurrent Irradiation of elemental standards with the sample to be analyzed.)

The counting schedule in the current analysis of both coal and flyash standard reference materials was exactly that shown in Table 1 . Irradiation times and sample sizes for the two matertals were as follows:
Table 4. I.imits of detection $\left(\mathrm{ng} / \mathrm{m}^{3}\right.$ above blank for trace eltments in aerosols with instrumental neucron activation.

\begin{tabular}{|c|c|c|}
\hline \multirow[b]{2}{*}{ Element } & \multicolumn{2}{|c|}{$\begin{array}{c}\text { Detection limit } \\
\text { (ng/m }{ }^{3} \text { above blank) }\end{array}$} \\
\hline & $\begin{array}{l}\text { Gelman } \\
\text { GA-1 }\end{array}$ & $\begin{array}{l}\text { Impactor } \\
\text { fi }{ }^{\mathrm{a}} \mathrm{m}^{\mathrm{a}}\end{array}$ \\
\hline $\mathrm{Na}$ & 300 & 200 \\
\hline $\mathrm{Mg}$ & 100 & 10 \\
\hline Al & 0.3 & 100 \\
\hline $\mathrm{Cl}$ & $i$ & 1 \\
\hline $\mathrm{Ca}$ & 1 & 10 \\
\hline $\mathrm{TI}$ & 10 & 1 \\
\hline v & & 0.1 \\
\hline Mth & 0.6 & \\
\hline $\mathrm{Cu}$ & 0.1 & 1 \\
\hline $\mathrm{Br}$ & & 0.0003 \\
\hline In & 0.002 & 0.0004 \\
\hline I & & 0.02 \\
\hline $\mathrm{Ba}$ & 2 & 0.5 \\
\hline $\begin{array}{l}\text { a Average } \\
0.0025 \text { a } \\
\text { polyethy } \\
\text { sticky re }\end{array}$ & $\begin{array}{l}\text { ts for } \\
\text { on, and } \\
\text { overed }\end{array}$ & $\begin{array}{l}6 \mathrm{~cm} \text { Mylar } \\
25 \mathrm{~cm} \\
0.004 \mathrm{~cm}\end{array}$ \\
\hline
\end{tabular}

Short Irradlation

Material

Coal (SRM 1632) Amount Time

Flux $100 \mathrm{mg}$

Flyash (SM 1633) $100 \mathrm{mg}$
$2.1 \times 10^{13}$

$15 \mathrm{sec}$

$2.1 \times 10^{13}$
Long Irradiation

Amount Time Flux
$200 \mathrm{mg} \quad 60 \mathrm{~min} \quad 2.6 \times 10^{13}$ 100 ing $60 \mathrm{~min}$
The results of these analyses are compared with those reported by Ondov et al. ${ }^{11}$ and by NBS in Table 5 . Elemental concentration data were obtained in the current analyses for Mo, Nd, and Dy, but for these elements no data were available for comparison. 
Table 5. Comparison of LLL INAA results for NBS standard reference material coal and flyash to results reported by NBS and by ondov et al. 11 $(\mu g / g \pm 2 \sigma$ unless \% inds cated).

\begin{tabular}{|c|c|c|c|c|c|c|}
\hline & \multicolumn{3}{|c|}{ NBS coal SRM } & \multicolumn{3}{|c|}{ NBS flyash SRM 1633} \\
\hline & LLL (INAA) & Ondov et al. & NBS & LLL (INAA) & ondov et al. & NBS \\
\hline A1\% & $1.59 \pm 0.20$ & $1.85 \pm 0.13$ & & $12.1 \pm 0.5$ & $12.7 \pm 0.5$ & \\
\hline $\mathrm{Sb}$ & $3.4 \pm 0.1$ & $3.9 \pm 1.3$ & & $6.9 \pm 0.6$ & $6.9 \pm 6$ & \\
\hline As & $5.8 \pm 0.3$ & $6.5 \pm 1.4$ & $5.9 \pm 0.6$ & $64 \pm 4$ & $64 \pm 4$ & $61 \pm 6$ \\
\hline $\mathrm{Pa}$ & $302 \pm 8$ & $352 \pm 30$ & & $2510 \pm 160$ & $2700 \pm 200$ & \\
\hline $\mathbf{B r}$ & $17.2 \pm$ & $19.3 \pm 1.9$ & & $6.7 \pm 0.6$ & $12 \pm 4$ & \\
\hline $\mathrm{Ca}$ & $0.42 \pm 0.06$ & $0.43 \pm 0.05$ & & $4.2 \pm 0.2$ & $4.7 \pm 0.6$ & \\
\hline $\mathrm{Ce}$ & $18.8 \pm 1.0$ & $19.5 \pm 0.1$ & & $148 \pm 6$ & $146 \pm 15$ & \\
\hline Cl & $828 \pm 22$ & $890 \pm 125$ & & - & $42 \pm 10$ & \\
\hline $\mathrm{Ce}_{\mathrm{B}}$ & $1.40 \pm 0.08$ & $1.4 \pm 0.1$ & & $8.6 \pm 0.8$ & $8.6 \pm 1.1$ & \\
\hline $\mathrm{Cr}$ & $17.6 \pm 1.0$ & $19.7 \pm 0.9$ & $20.2 \pm 0.5$ & $117 \pm 7$ & $127 \pm 6$ & $131 \pm 2$ \\
\hline Co & $5.51 \pm 16$ & $5.7 \pm 0.4$ & & $39.4 \pm 1.2$ & $41.5 \pm 1.2$ & \\
\hline Eu & $0.27 \pm 0.02$ & $0.33 \pm 0.04$ & & $2.39 \pm 0.11$ & $2.5 \pm 0.4$ & \\
\hline $\mathrm{Hf}$ & $1.00 \pm 0.07$ & $0.96 \pm 0.05$ & & $7.2 \pm 0.6$ & $7.9 \pm 0.4$ & \\
\hline In & $0.03 \pm 0.02$ & $0.20 \pm 0.12$ & & $0.27 \pm 0.14$ & $0.32 \pm 0.10$ & \\
\hline $\mathrm{Fe}$ & $0.84 \pm 0.02$ & $0.84 \pm 0.04$ & $0.87 \pm 0.03$ & $6.8 \pm 0.03$ & $6.2 \pm 0.3$ & \\
\hline La & $9.5 \pm 0.2$ & $10.7 \pm 1.2$ & & $81 \pm 2$ & $82 \pm 2$ & \\
\hline Mg & $0.25 \pm 0.08$ & $0.20 \pm 0.05$ & & $2.0 \pm 0.4$ & $1.8=0.4$ & \\
\hline Mn & $39.5 \pm 0.7$ & $43 \pm 4$ & $40 \pm 3$ & $505 \pm 14$ & $496 \pm 49$ & $493 \pm 7$ \\
\hline K & $0.27 \pm 0.02$ & $0.28 \pm 0.03$ & & $1.75 \pm 0.18$ & $1.61 \pm 0.15$ & \\
\hline $\mathrm{Rb}$ & $19.0 \pm 1.5$ & $21 \geq 2$ & & $105 \pm 10$ & $125 \pm 10$ & \\
\hline Sm & $1.72 \pm 0.08$ & $1.7 \pm 0.2$ & & $13.0 \pm 0.7$ & $12.4 \pm 0.9$ & \\
\hline Se & $3.68 \pm 0.08$ & $3.7 \pm 0.3$ & & $27.0 \pm 0.6$ & $27 \pm 1$ & \\
\hline s1 & $2.9 \pm 0.4$ & $3.4 \pm 0.2$ & $2.9 \pm 0.3$ & $9.0 \pm 1.4$ & $10.2 \pm 1.4$ & $9.4 \pm 0.5$ \\
\hline $\mathrm{Na}$ & $380 \pm 12$ & $414 \pm 20$ & & $3240 \pm 100$ & $3200 \pm 400$ & \\
\hline Sr & $112 \pm 26$ & $161 \pm 16$ & & $1250 \pm 230$ & $1700 \pm 300$ & \\
\hline Ta & $0.23 \pm 0.02$ & $0.24=0.04$ & & $2.0 \pm 0.2$ & $1.8 \pm 0.3$ & \\
\hline $\mathrm{Tb}$ & $0.20 \pm 0.02$ & $0.23 \pm 0.05$ & & $1.87 \pm 0.15$ & $1.9 \pm 0.3$ & \\
\hline Th & $2.9 \pm 0.1$ & $3.2 \pm 0.2$ & & $23.6 \pm 0.8$ & $248 \pm 2.2$ & \\
\hline$T \pm$ & $1000 \pm 260$ & $1040 \pm 110$ & & $7150 \pm 1200$ & $7400 \pm 300$ & \\
\hline w & $0.65 \pm 0.15$ & $0.75 \pm 0.17$ & & $5.5 \pm 1.5$ & $4.6 \pm 1.6$ & \\
\hline v & $1.24 \pm 0.05$ & $1.41 \pm 0.07$ & $1.4 \pm 0.1$ & $10.5 \pm 1.0$ & $12.0 \pm 0.5$ & $11.6 \pm 0.2$ \\
\hline v & $41 \pm 10$ & $36 \pm 3$ & $35 \pm 3$ & $290 \pm 80$ & $235 \pm 13$ & $214 \div 0.8$ \\
\hline $\mathrm{Yb}$ & $0.75 \pm 0.03$ & $0.7 \pm 0.1$ & & $5.9 \pm 0.3$ & $7 \pm 3$ & \\
\hline an & $43 \pm 2$ & $30 \pm 10$ & $37 \pm 4$ & $230 \pm 40$ & $216 \pm 25$ & $210 \pm 20$ \\
\hline $\mathbf{z r}$ & $28 \pm 24$ & - & & $182 \pm 76^{*}$ & $301 \pm 20$ & \\
\hline
\end{tabular}

Zr value $182 \pm 76 \mu \mathrm{g} / \mathrm{g}$ was corrected for ${ }^{235} \mathrm{U(n,f)}{ }^{95} \mathrm{Zr}$ contribution. Uncorrected value was $295 \mu \mathrm{g} / \mathrm{g}$. 


\section{Applications}

The major area of application of the LLL instrumental neutron activation capability is in the multielement analysis of samples derived from large scale environmental studies. In the Environmental Research Programs the anaiytical capability of INAA is supplemented by nondispersive $x$-ray fluorescence analyses (XRF $A$ ), which also provides multielement analysis but for a different group of elements than INAA. Elements of particular interest that are not measurable either by INAA or by XRFA are analyzed by atomic absorption analysis. The overall analytical program provides an appropriate combination of the analytical methods that depends on the elemental abundance information that is required. This section describes the major prograns for whici elemental analysis data have been provided. The programs are grouped according to whether they are completed or are continuing. In addition to the major programmatic analyses described below, analyses are performed in response to particular individual or one-time problems.

COMPLETED ENUTRONHENTAL STUDIES

The California Aerosol Characterization Experiment (ACHEX) 1972-1974 Some of the more pressing ques- tions of air pollution requiring improved knowledge are those dealing with aerosols. Although airborne particles represent a small fraction of the load of traceconstituents in air, they contribute significantly to environmental degradation as a potential hazard to health, a visibility reducer, and a posstble agent of weather modif1cation. Despite many years of investigation, the orlgins and evolution of atmospheric aerosols remain poorly understood compared with trace gases. Recognizing this, the Californla Air Resources Board (ARB) sponsored a major survey of aerosols In urban and remote sites of California. 12

The project was designed to study primary particie sources, atmospheric formation, and their relationship to changes in visibilitya In California, the secondary production of aerosols by chemical and physical processes in the atmosphere is believed to be especlally important。

The objectives of the study to which INAA were applied were:

- To characterize the aerosol in the basins of the Southern California Coast, the San Francisco Bay Area, and the San Joaquin Valley in terms of its interaction in the atmosphere 
and its natural and anthropogenic origins.

- To evaluate the amount of the atmospheric aerosol in these three major air basins that can be related to primary emissions suci as from auto exhausts or smokestacks and secondary production resulting from physical and chemical processes in the atmosphere.

- To Identify those major sources of particles that can be related to aerosol pollution and reduction In visibility.

- To evaluate the applicability of the aerosol analysis instrumentation employed in this study for use in present mnitoring networks.

The results of the experiment revealed extremely complicated behavfor of atmospheric aerosols, as they ore influenced by local sources, gasparticle interaction, and meteorological factors. However, they were found to have certain important common features. For example, the effort showed clearly that man's activities and atmospheric transformations of gaseous pollutants contribute primarily to the subnicron particle size range, while natural sources influence chiefly the range $>1-j$ m diameter.

Approximately 700 filter and impactor samples were analyzed during the study. Total aerosol specimens were collected on $5-\mu m$ cellulose acetate membrane filters in low-volume air samplers。 Multistage, rotating-drum, cascade impactors were used to collect size-segregated atrosols. The particle-slze distributions obtained had $50 \%$ cut points of $8.0,4.0,1.5$, and $0.5 \mu \mathrm{m}$. Cellulose acetate afterfilters cullected particles <0.5 $\mathrm{\mu m}$.

The aerosol spectmens were routinely analyzed for $\mathrm{Na}, \mathrm{Mg}, \mathrm{Al}, \mathrm{Cl}$, $\mathrm{Ca}, \mathrm{Ti}, \mathrm{V}, \mathrm{Mn}, \mathrm{Cu}, \mathrm{Br}, \mathrm{In}, \mathrm{I}$, and $\mathrm{Ba}$ with a $2-m i n$ irradiation at $3 \mathrm{MW}$ in the LPTR followed by $9-$ and $20-m 1 n$ counts. Sensitivities obtained for 10 of the elements were routinely less than $10 \mathrm{ng} / \mathrm{cm}^{3}$. Selected samples were further analyzed for Eu, $\mathrm{Ce}, \mathrm{Se}, \mathrm{Th}, \mathrm{Cr}, \mathrm{Hf}, \mathrm{Ag}, \mathrm{NI}, \mathrm{Sc}, \mathrm{Fe}$, $\mathrm{Zn}$, and $\mathrm{Co}_{0}$, using a 12-hr 1rradiation followed by an B00-min count after a 3-wk decay.

The California Aerosol Characterization Experiment data on the distribution of aerusol constituents with size confirm the hypothesis that constituents originating from certain sources dominate the mass in particular size ranges. Material from combustion, chemical, and metal refining sources appear largely in the submicron (or anthropogenic) fraction. Examples include $\mathrm{Br}, \mathrm{C} 1$, and V. In the supermicron fraction appear the natural or quasinatural elements such as $\mathrm{Na}, \mathrm{C1}, \mathrm{Al}, \mathrm{Fe}, \mathrm{Ca}$, and $\mathrm{Sc}$. In this study the natural background aerusol consisted of a mixture of sea 
salt, soil dust, and a residue of aged aerosol transported from a distant urban area.

Aluminum was found principally in the larger particles ( 8 to $15 \mathrm{fm}$ ) at all urban, inland, and coastal sites. Since large particles are usually a result of windblown eroded soll, the Al corcentration was used as an indicator of the amount of soll component in the aerosols. Other elements with Al-like distributions were $\mathrm{Ca}, \mathrm{Mg}$, $\mathrm{Mn}, \mathrm{Sc}, \mathrm{Th}, \mathrm{Fe}$, and Co, Implying they were also derived from soll. The vanadium distributions were bimodal with maxina at submicron ranges $(<0.5 \mu \mathrm{m})$ and large particle sizes $(<8.0 \mu \mathrm{m})$. These data suggest two sources of vanadium, soll dust and combustion (probably the burning of residual fuel o11) processes.

The sodium at coastal sites was from sea salt and present in the 1.5 to 4.0 $\mu m$ particle size range. The sodium at inland sites was derived from soil erosion and found in the large-particle range, 8 to $15 \mu \mathrm{m}$. At coastal sites the chlorine distribution followed the sodium distribution. At inland sites the submicron $\mathrm{Cl}$ (as well as $\mathrm{Br}$ ) that resulted from automotive emisstuns increased significantly.

A secondary but important role of INAA was the validation of other analytical techniques utilized in the chemical analysis of aerosols. Supplemental experiments were also per- formed using INAA to validate the collection efficiencles of rotatingstage cascade impactors.

As a result of these studies, it was concluded that techniques using INAA were useful operational methods for chemical analysis of aerosol samples taken over 2-hr periods in urban air in an active monitoring program. These techniques have been summarlzed in Ref. 9.

\section{Air Sampling in the Vicinity of} Smelting Operations

An example of what can be accomplished in aerosol characterization Is shown by a study of air filter samples collected at Kellogg, Idaho, 13 In the Coeur d'Alene mining district. Samples were analyzed to determine the concentrations of trace metallic elements in $+!$ air, and to look for Indications of " - ir sources. For example, some elements are in the air as a result of the mining and smelting operations, others have been picked up from soil surfaces by the winds.

Samples were analyzed for 34 elements with INAA, and for 6 elements with XRFA. Elemen:s were divided Into three maIn groups according to their enrichment factors (defined as enrlchment of concentration relative to the local average In the Kellogg Valley solls). Elements with low enrlchment factors $(<100)$ were considered to originace primarlly from 
the soil. Those with an intermediate enrichment factor ( 100 to 1000) were considered to be of uncertain origin (soil and/or mining and smelting). Those with a high enrichment factor $(>1000)$, were considered to be clearly from mining or smelting.

The relationship between the results of XRFA and INM is show in Fig. 8 for Cu, Br, ie, and in. The solid line represents a correlation coeffleient of 1.0 , or perfect correlation. The linear correlation coefilcients of these four elements are $0.98,0.96,0.93$, and 0.97 , respectively, for Cu, Br, Fe, and zh.
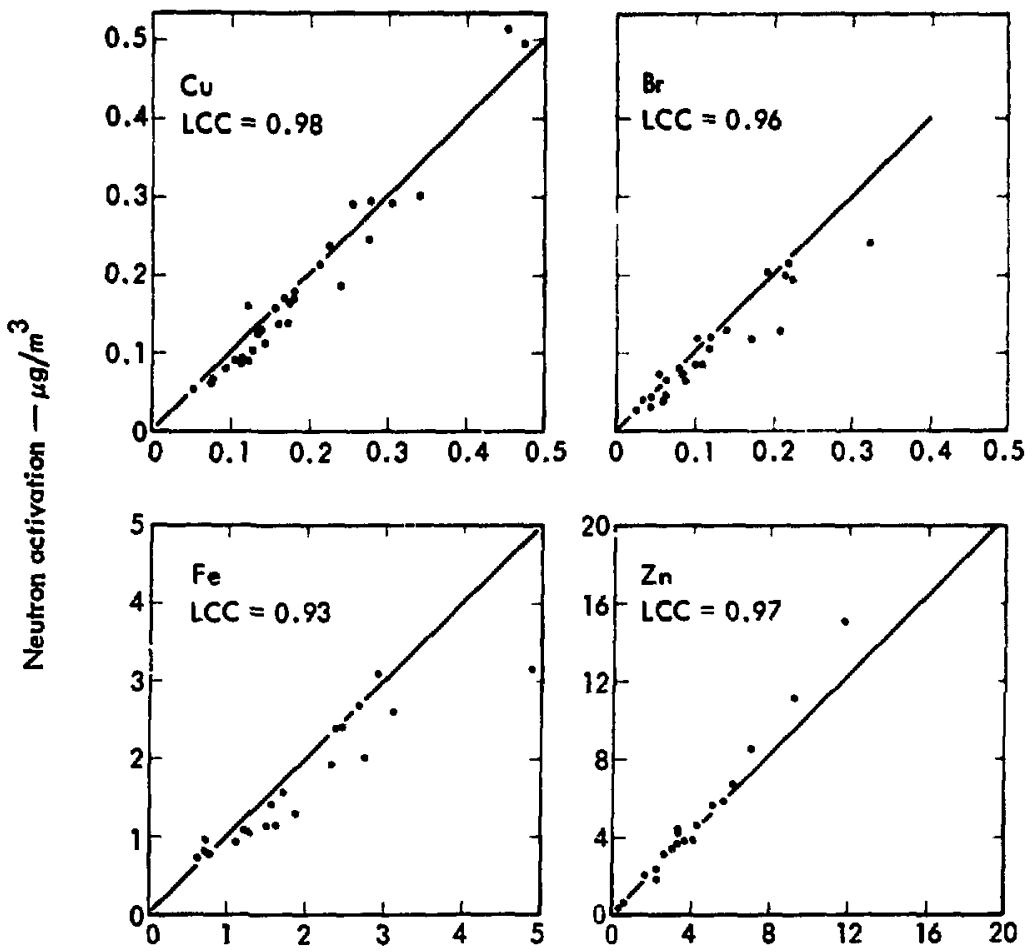

$X$-ray fluorescence $-\mu g / m^{3}$

Fig. 8. Correlation of INAA and KRFA results for $\mathrm{Cu}, \mathrm{Br}, \mathrm{Fe}$, and $\mathrm{Zn}$. Linear correlation coefficient (LCC) values are shown: a value of 0.35 or higher indicates a positive correlation. 


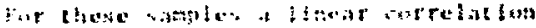

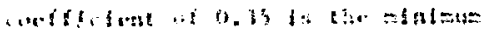

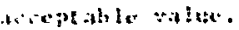

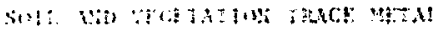

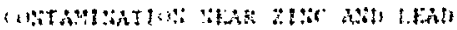

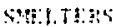

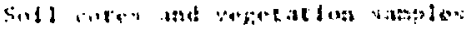

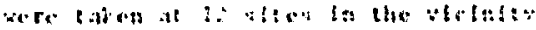



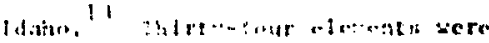

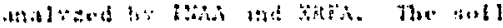

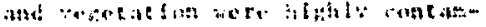

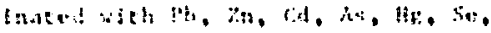

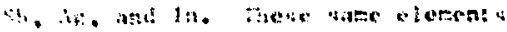

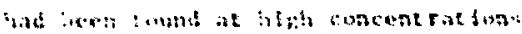

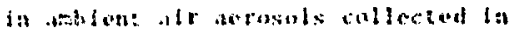

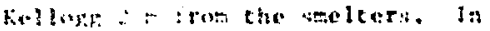

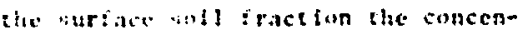

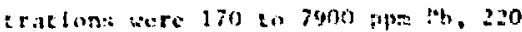

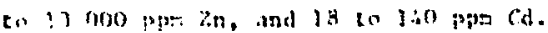
in the vepetation the concentrit lons

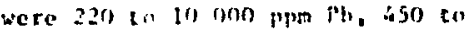
12 (ono pom $\mathrm{zn}$, and in to $950 \mathrm{ppm}$ ca. The acrosol enrlehnent fackors relitive the mein concentrit tons in the surface soll were $\$ 100$ for cd, iso for As, 110 for Pl: and 60 for $Z \mathrm{n}$.

CONTINUING ENYIROAMENTN. STUDIES

\section{Trace Elcments in Milk}

The role of trace elements in tire environment boch as coxic materlals and as essential nutrients for plants, antmals, and man is well recognized.

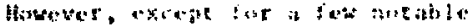

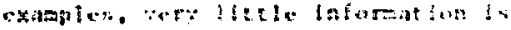

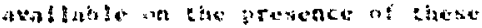

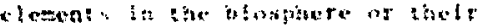

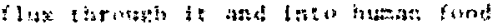

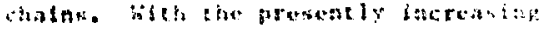



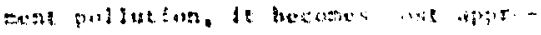

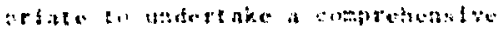

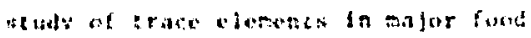



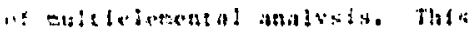

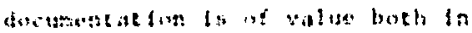

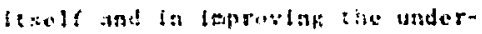

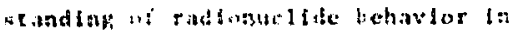

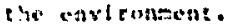


phase of thlis Netuly, Mitch l:s a sur4ov uf trace claments in market milk colloced in calitornla ind Colorido, hise been reported in thet. 1:. Aria-

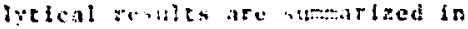
Tables is and 7 . This surver served as i focus for developing procadures for the assay af trace elements by

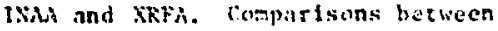
the two cecinlques were carried out

Table 6. Mnor constituents in market on $11 \mathrm{k}=\mathrm{g} / \mathrm{h}$.

\begin{tabular}{|c|c|c|c|c|}
\hline Elecent & צc.n & $\frac{\text { Min vork }}{\text { Standard }}$ & Ranfe & $\frac{\sec .15}{40.15}$ \\
\hline $\mathrm{ca}$ & 1.17 & 0.09 & $1,0:-1, \therefore 5$ & 2.23 \\
\hline$M_{p}:$ & n.:11 & $0.0 \pm 6$ & $0.04-0.17$ & 0.1 ? \\
\hline sin & 0.536 & $0.0 \% 2$ & $0.33=0.61$ & 0.55 \\
\hline N & 1.65 & 0.18 & $1,32=2,00$ & $1 . .1$ \\
\hline CI & 1.00 & 0.10 & $0.80-1 . \therefore$ & $1 .: 2$ \\
\hline
\end{tabular}


Table 7. Trace elements in rarket milk $-\mathrm{mg} / \ell$.

\begin{tabular}{lllll}
\hline & \multicolumn{2}{c}{ This work } & \multicolumn{1}{c}{ Ref. 16 } \\
\cline { 2 - 5 } Element & Nean & $\begin{array}{c}\text { Standard } \\
\text { deviation }\end{array}$ & Range & Range \\
\hline Al & 1.64 & 0.38 & $1.1-2.8$ & $1.4-17.0$ \\
Co & 0.0126 & 0.0336 & $0.0003-1.8$ & $0.1-0.9$ \\
Fe & 0.75 & 0.62 & $0.2-2.7$ & $0.3-1.5$ \\
Rb & 1.40 & 0.81 & $0.6-45$ & $0.6-3.4$ \\
In & 3.80 & 0.50 & $2.8-5.0$ & $1.0-5.0$ \\
Cs & 0.0035 & 0.0025 & $0.001-0.012$ & Not g1ven \\
Br & 3.60 & 1.30 & $1.56-6.13$ & $1.0-8.0$ \\
I & 0.44 & 0.19 & $0.16-0.96$ & $0.07-1.61$ \\
Se & 0.0231 & 0.0085 & $0.012-0.049$ & $0.015-0.048$ \\
Sr & 1.30 & 1.40 & $0.65-9.3$ & $0.10-1.51$ \\
\hline
\end{tabular}

The number 9.3 was single high value. Next highest was $1.6 \mathrm{mg} / \mathrm{l}$.

to validate the analytical procedures. Collection procedures were also tested and validated during the course of the seudy.

\section{Marine Studies of Coastal Reactors}

Reactors located on the coast can use sea water for cooling and for disposing of low level radioactive wastes. The Environmental Research Division had undertaken a coastal studies program deslgned to invest1gate the fate of radionuclides released into a marine environment. One phase of the program Involved the study 17 of the Pactfic Gas and Electric Company reactor at Humboldt Bay where over a 3-yr period all reactor releases were assayed for radionuclide composition and concentration and the uptake of the radionuclides by sediments and biota was followed. Stable element concentrations in the various environmental compartments were determined by neutron activation analysis. The concentration of the stable element counterpart of each of the radionuclides released should be determined in each compartment to unterstand the observed radionuclide partitioning. Thus, if we know that in a particular aqueous pool the ratio of radioactive ${ }^{65} \mathrm{Zn}$ to stable $\mathrm{Zn}$ is $0.3 \mathrm{pCi} / \mu \mathrm{g}$; and if we know that mature oysters have stable $\mathrm{Zn}$ concentrations of $4000 \mathrm{\mu g} \mathrm{Zn} / \mathrm{kg}$ wet welght of oyster, then we expect the concentration of radioactive ${ }^{65} \mathrm{Zn}$ in the oysters to reach $0.3 \times 4000$ or $1200 \mathrm{pCi} / \mathrm{kg}$ wet welght. 
Elements of interest in the coastal studies program are those having a radioactive counterpart that is released into the marine environment. Since these are all relatively longlived species produced by neutron capture, INA is particularly appropriate for their determination. For the Humboldt Bay study elements of interest were $\mathrm{Cs}, \mathrm{Ce}, \mathrm{Mn}, \mathrm{Zn}$, and $\mathrm{Co}$. These were determined for three main categories of sample - seawater, sediment, and blota. Seawater samples were filtered and acidified at the point of collection. At the laboratory, the trace elements from 4-? samples were preconcentrated, first by evaporation to reduce volume by a factor of 4, and second by selectively precipitating elements of interest to eliminate the major interference of sodium in seawater. The ashed precipitates were irradiated for $8 \mathrm{hr}$, cooled for 1 wh, and counted to determine the quantity of the activation products.

Sediment samples were dried and then $100 \mathrm{mg}$ aliquots were irradlated, cooled, and counted using the same schedule as above. This schedule was also followed for the bfota samples. In this case, however, the original bfological material was first drfed and then ashed at $450^{\circ} \mathrm{C}$ to provide a 100-mg sample.

In all cases, additional elements (Sc, v, Th, Cr, Nd, Mo, Fe, Sm, Ag,
$R b$, and $\left.E_{4}\right)$ were routinely determined by the analysis although not all were determined on every type of sample. A similar program in which the elemental concentrations in marine organisms are determined is being conducted of the Diablo Canyon Reactor site (San Luis oblspo, California).

\section{Trace Contaminants From Coal Fired}

Power Plants

As a result of recent efforts to reduce U.S. dependency on foreign oll for power production, construction of coal-fed electrical generating stations is increasing at unprecedented rates. It is we11-documented that high-teluperature combustion processes, such as fossil-fuel power production, are responsible for mobilizing vast quancities of toxic substances by injection of both vapor-phase (metal1ic) species and submicron particles into the atmospinere. Submicron particles are particularly hazardous because $50 \%$ of the inhaled particles between 0.01 and $0.1 \mu \mathrm{m}$ deposit in the alveoli of the lung where most trace elements are readily absorbed into the blood stream. The work reported here is part of an effort at the Lawrence Livermore Laboratory to assess the impact of coal-fed power plant emissions as the resulting dose fncrement to man. The first phase of the program is the characterization of trace-element emissions, 
In rerms vi quancley and partlelesize distribution. Particular emphasis is given to primary factors affecting the characteristics of trace-element emission such at elemental concentrations in coal, coal chemistry, vapor-phase/particulate fractionation, operation cemperacures, and type and efflofency of pollutioncontrol equipment. This information could be used in conjunction with models of atmosfherle transport and lung deposition to predict increases in blood and whole body levels of toxic trace elements resulting from the operation of a proposed power installation.

The complete elemental anslysis of coal, flyash, and stack effluents from two western coal-fired plants by INAA, XRFA, and atomic absorption is in progress. Several hundred samples have been analyzed thus far. Preliminary results from this program are given in Reference 18. Figure 9 shows some typical distributions of elemental particle size in flyash emitted from one of the coal-fired power plants studied. The elements emitted from the unit equipped with a wet-venturi scrubber emission-control system are concentrated on submicron particles, whereas the elemental emissions from the unit equipped with an electrostatic precipitator are concentrated on supermicron particles. These effects occur because of the signiff- cant differences in collection efficlency as a function of particle stze between the two types of emtisition control devices. The health implications of chese data are prosented elsewhere.

Imperial Valley Environmental Project (IVEP)

The ?awrence l.Ivermore Luhoratory has been appointed by the U.S. linergy Research and Development Mdministrition to be the lead laboratory for a long-term project to acquire complete understanding of the environmental quality in the Imperial Valley of California prior to any major developments. The purpose of this project Is to ensure that the development of geothermal resources froceeds on an envitronmentally sound basis. Consequently, the Imperial Valley Environmental Project (IVEP) is conmitted to an intensive and compreherisive study designed to establish an environmental baseline for the I.npertal Valley as well as to develop an understanding of environmental and ther effects associated with development of geothermi: resources. 20

The LLL elemental analys is group is responsible for the analysis of certain categories of samples resulting from IVEP for analytical quality control for data produced by other laboratories. The scope of the analysis progran is being established. 


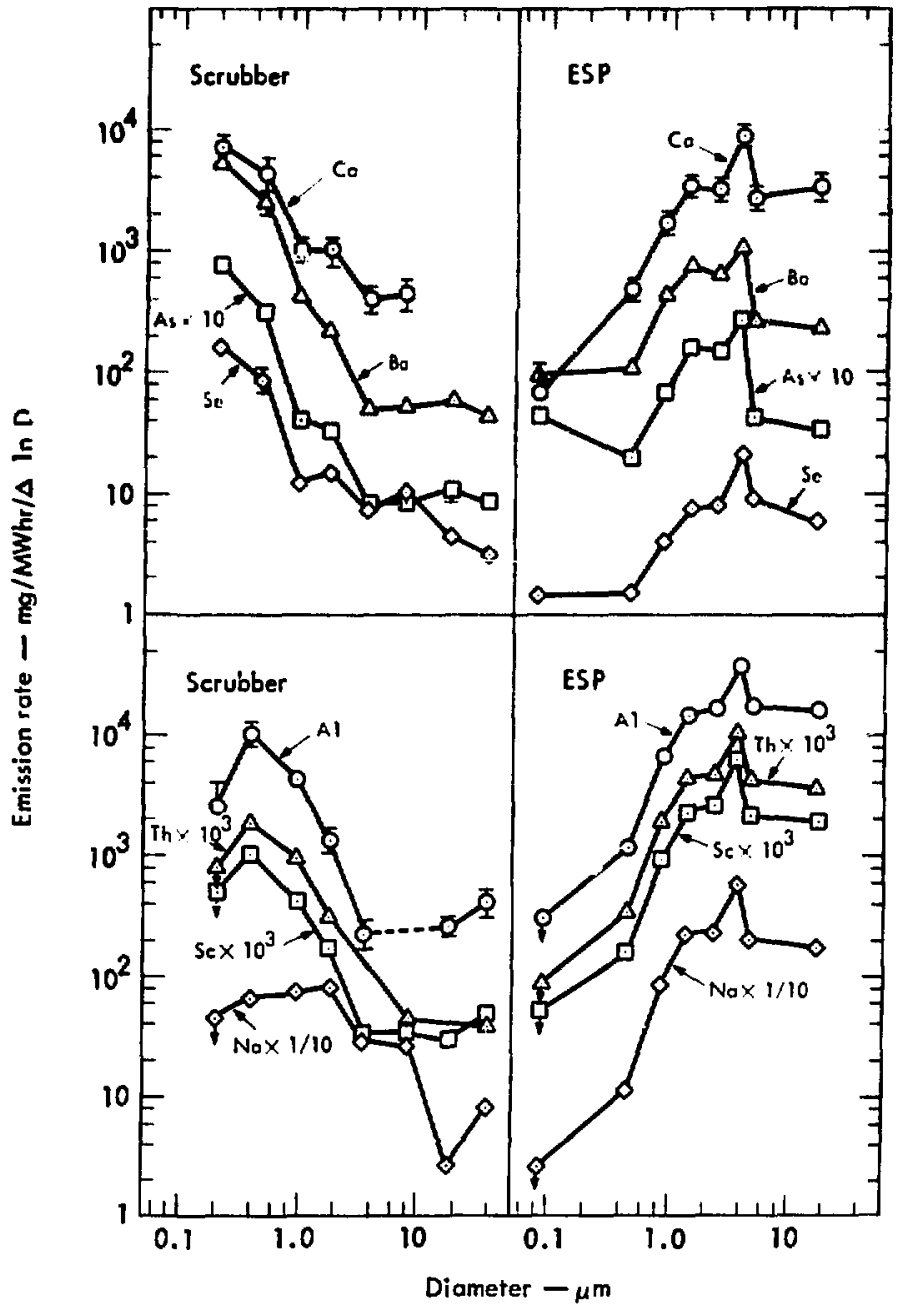

Fig, 9. Typical particle size distributions for several elements determined on particles collected downstream from a wet venturi scrubber and an electrostatic precipitator. 


\section{References}

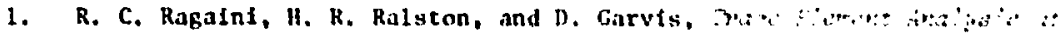

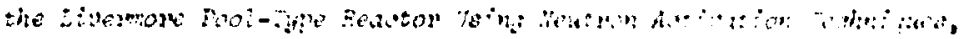
Lawrence LIvermore laboratory, kept, LCKL-5IB55 (1975).

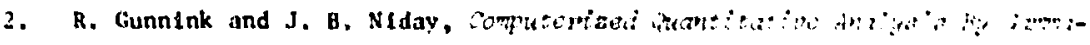

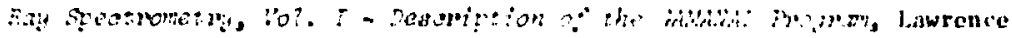
Livermne Laboratory, Rept. UCRL-S106I Vol. I (1972).

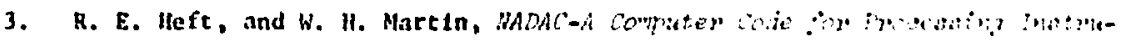
menta? Veatso: Aotintion Data, Lawrence Livermore Laboratory, Rept. in preparacton.

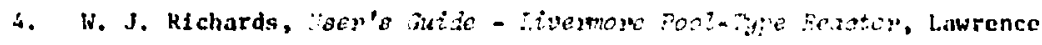
Livermore Laboratory. Manual $\because-0.5]$ Sej. I (1975).

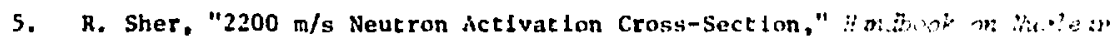
iativation aros-iections, International Atomic Energy Agency, Technical Report Series No. 156, Vienna (1974).

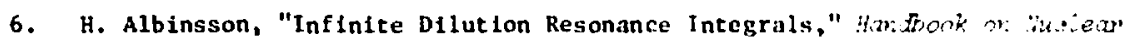
Aativation Crose-seasions, International Atomlc Energy Agency, Technical Report Series No. 156, Vienna (1974).

7. R. Van DC- LInden, F. De Corte, and 3. Hoste, "Resonance Integrals Applfed to the Multiple-Comparator Method in Keactor Neutron Activation Analysis", Nuclear Data In Science and recinology Vot. IT. International Atomic Energy Agency, Vienna (1973).

8. G. Gleason, "Thermal Neutron Cross-Section and $(n, \gamma)$ Resonance Incegrals Part I," Radiochem. Fadioanal, Lett. 23 (5-6), 317 (1975).

9. N. J. Roberts, Aerosol Prace Element Analysis ising Heutror Aativation and X-Ray Flworescence, Lawrence Livermore Laboratory, Rept. UCRL-51499 (1974).

10. R. C. Ragaini, H. R. Ralston, D. Garvis, and R. Kaifer, Trace Elements in Califormia Aerosols. Part I, Lawrence Livermore laboratory, Rept. UCRL-51850 (1975).

11. J. M. Ondov, W. H. Zoller, I. Olmez, N. K. Aras, G. E. Gordon, L. A, Rancitelli, K. H. Abel, R. H. Filby, K. R. Shah, and R. C. Ragaini, "Elemental Concentrations in the National Bureau of Standards' Environmental Coal and FIy Ash Standard Reference Materials," Anal. Chem. 47, 1102 (1975). 
12. Toracterisation of heroaole in Califomia - Final Report, Rockwell International Sclence Center, Rept, SC524,25FR (1974).

13. R. C. hagainl, H. R. Ralston, N. Roberts, D. Gorvis, and A. Langhorst, Envimmental. Thace Metal Contamination in Kellogg, Idaho, Near Zinc and Lead Imeltern, Lawrence L.Ivermore Laboratory, Rept. UCRL-77733 (1976).

14. R, C. Ragalni, A. L. Iangherst, H. R, Ralston, and R, Heft, Instromental trace Element Analyoia of Califormia Market Mizk, Lawrence hive tmore Laboratory, Rept . UCRL-51859 (1975).

15. B. 11. Wabb and A, H. Johnson, Fundanental of Dairy Chemiotry (The AVI. Publlshing Co., Westport, Conn., 1965), p. 19.

16. C. K. Murthy, "Trace Elements in M11k," CRC Crit. Rev. Environ. Controi 4(1), 1 (1974).

17. R. E. Heft, W. A. Phillips, H. R. Ralston, and W. A. Steele, "Radionuclide Transport Studies in the Humboldt Bay Marine Environment," Radioactive Contanination of the Marine Environment, International Atomic Energy Agency, SM-158/37, Vienna (1973).

18. R. C. Ragaini and J. M. Ondov, "Trace Contaminants From Coal-Fired Power Plants," in Proc. Int. Conf. Environ. Sens. Assess., Las Vegas, 1975, p. 17-2; Lawrence Livermore Laboratory, Rept. UCRL-76794 (1975).

19. J. M. Ondov, R, C. Ragain1, and A. H. Blerman, Comparison of Particulate Enissions from a Wet Scmbber and Electrostatis Precipitation at a CoalFijed Power Plant, to be presented at American Chemical Society Meeting, San Francisco, California, August i9-September 3, 1976; Lawrence L1vermore Laboratory, Rept, UCRL-78050 (1976).

20. L, R. Anspaugh and P. L. Phelps, An Overview of the Imperial Valley Environmental Project, Lawrence Livermore Laboratory, Rept. UCID-17067 (1976). 